\title{
Use of DoE methodology to optimize the regeneration of high-quality, single-copy transgenic Zea mays L. (maize) plants
}

\author{
Uyen Cao Chu ${ }^{1} \cdot$ Jeffrey Adelberg ${ }^{2} \cdot$ Keith Lowe ${ }^{1} \cdot$ Todd J. Jones $^{1}$ (I) \\ Received: 10 September 2018 / Accepted: 4 July 2019 / Published online: 7 August 2019 / Editor: Randall P. Niedz \\ (C) The Author(s) 2019
}

\begin{abstract}
The maize Agrobacterium tumefaciens-mediated transformation process normally takes about 10 to $15 \mathrm{wk}$ from embryo infection and co-cultivation to sending "T0" plants to the greenhouse (GH). A new method was developed using the maize transcription factors Babyboom (BBM) and Wuschel2 (WUS2), to stimulate direct transgenic embryo formation and plant regeneration, that bypasses the need for prolonged tissue culture and regeneration from callus. In the present study, a design of experiment (DoE) method was used to test 10 factors to optimize the quality of somatic embryo maturation, root formation, and subsequent plantlet survival, without compromising the molecular event quality. The concentration of $\mathrm{NO}_{3}{ }^{-}$and the ratio of $\mathrm{NH}_{4}{ }^{+}$to $\mathrm{K}^{+}$had significant effects on the morphology of plantlets derived directly from germinated transgenic embryos. During early development, optimal tissue morphology required a $\mathrm{NH}_{4}{ }^{+} / \mathrm{K}^{+}$ratio of $1: 1$ with $20 \mathrm{mM}\left[\mathrm{NO}_{3}{ }^{-}\right]$, of $14.2 \mu \mathrm{M}$ 6-benzylaminopurine (BAP), the highest concentration tested, and a low light intensity of $50 \mu \mathrm{mol} \mathrm{m} \mathrm{m}^{-2} \mathrm{~s}^{-1}$. Later development of rooted shoots required additional macronutrients with reduced $\mathrm{NH}_{4} \mathrm{NO}_{3}\left(15 \mathrm{mM} \mathrm{NH}_{4} \mathrm{NO}_{3}\right.$ and $\left.25 \mathrm{mM} \mathrm{KNO}_{3}\right)$, reduced BAP $(7.4 \mu \mathrm{M})$, and $1 \mu \mathrm{M}$ abscisic acid (ABA) and at a higher light intensity of $140 \mu \mathrm{mol} \mathrm{m}^{-2} \mathrm{~s}^{-1}$. Using the optimized parameters, the frequency of plants sent to the GH was improved by twofold compared with the current process and the number of single-copy T-DNA events was doubled.
\end{abstract}

Keywords Design of experiment (DoE) · Transgenic maize · Maize transcription factor BBM · Maize transcription factor WUS2 · Maize transformation method

\section{Introduction}

The demand for food crop production is expected to rise considerably over the next several decades to keep up with population growth (Tilman et al. 2011). To achieve this goal, farmers will need crops with biotechnology traits such as insect resistance and drought tolerance (Qaim and Kouser 2013). Efficient transformation systems are necessary to enable crop improvement with commercial traits. Since the discovery that immature Zea mays L. (maize) embryos could be

Electronic supplementary material The online version of this article (https://doi.org/10.1007/s11627-019-10002-w) contains supplementary material, which is available to authorized users.

Todd J. Jones

todd.j.jones@corteva.com

1 Corteva Agriscience ${ }^{\mathrm{TM}}, 8305$ NW 62nd Ave, Johnston, IA 50131, USA

2 Plant and Environmental Science Department, 275 Poole Agricultural Center, Clemson University, Clemson, SC 29634, USA used to initiate regenerable embryogenic callus (Green and Phillips 1975), most high-throughput maize transformation systems have relied on immature embryo-based callus formation. Using the traditional protocol (Fig. 1), immature embryos are transformed by Agrobacterium tumefaciens infection or by particle bombardment, and embryogenic callus is induced to proliferate from the transformed cells. The transformed cells are then clonally propagated under selective pressure into callus lines that can be regenerated into transgenic plants. This process is generally genotype dependent, labor intensive, and slow, with the process usually taking between 10 and $15 \mathrm{wk}$ from callus initiation to the regeneration of plantlets ("T0" plants) that can be transferred to soil and grown to maturity.

While many approaches have been tested with the goal to improve transformation process efficiency, few have focused on reducing the duration of the process. One important innovation that dramatically improves maize transformation frequency and efficiency is the use of two maize morphogenic genes that enhance tissue culture responsiveness and increase the recovery of transgenic plants. These two morphogenic genes, Babyboom (BBM) and Wuschel2 (WUS2), are both 
Fig. 1 Conventional Zea mays L. transformation process total elapsed time: from 155 to $203 \mathrm{~d}$. The process starts with isolating immature zygotic embryos and infection with Agrobacterium tumefaciens (co-cultivation). Embryos form callus and callus tissue goes through a maturation/ selection step. Following shoot regeneration, root production takes about 2 to 3 wk until plants are ready to be sent to the greenhouse. Transplanted T0 plantlets are grown to maturity, pollinated, and seed is harvested after approximately 3 to $4 \mathrm{mo}$

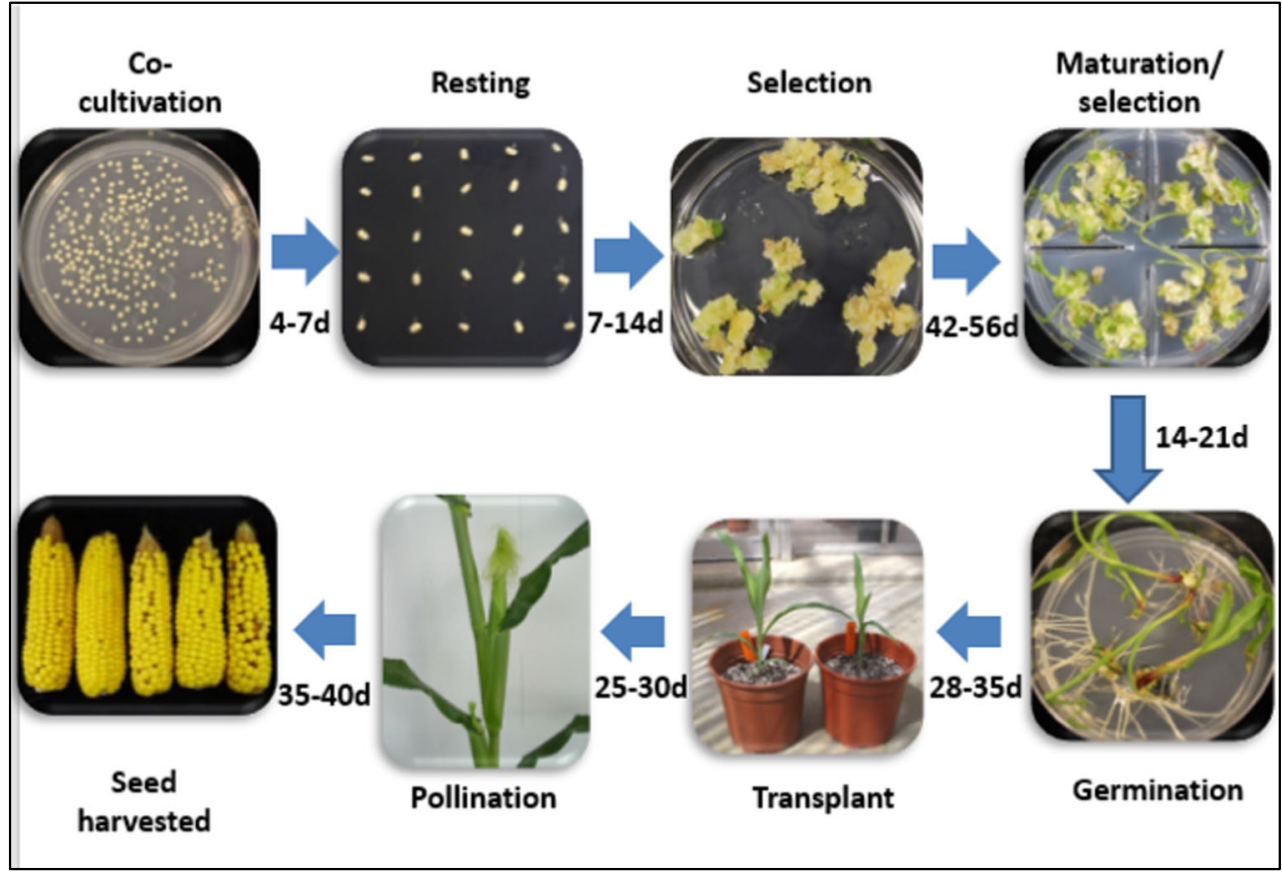

maize transcription factors (Lowe et al. 2016). Controlled expression of $B B M$ and WUS2 can be used to initiate wellformed somatic embryos directly from immature zygotic embryos explants. These somatic embryos can be regenerated into plants without an intervening callus phase (Lowe et al. 2018). This technology has been applied to other cereals (Anand et al. 2017) and is a new, rapid, universal transformation system for cereals. Because each somatic embryo is derived from a single transformed cell, every plant is a unique transformation event, and it is possible for transformation frequencies (transformants $\div$ starting embryos) to exceed $100 \%$. This system has the potential to be optimized into a rapid, genotype-independent transformation process, which can produce T0 plants in roughly half the time of the conventional method (Fig. 2).

The first report of fertile transgenic maize plants was published in 1990 (Gordon-Kamm et al. 1990). The target tissue for those experiments was embryogenic suspension cultures, derived from callus initiated from zygotic embryos. DNA was delivered by particle bombardment, and T0 plants were regenerated after about $16 \mathrm{wk}$. A considerable amount of research has been devoted to developing a robust process for transgenic maize plant production because the conventional method is time consuming, labor intensive, requires multiple media formulations, and necessitates numerous manual tissue transfers that can subject the process to errors. Additionally, care must be taken to prevent the regeneration of clonal plants that originate from the same callus event. With the new, rapid approach, the callus formation and selection stages are skipped altogether and transgenic somatic embryos are germinated directly. However, the germinated somatic embryos frequently possess weak root systems, and an additional root stimulation step is often necessary.

Transgene expression can be influenced by intactness of inserted T-DNA, copy number, neighboring endogenous gene expression, and the chromosomal insertion position (Iglesias et al. 1997). Multiple copy transgene insertions have been demonstrated to be susceptible to silencing in subsequent generations (Vain et al. 2002). Single-copy transgenic events have more consistent transgene expression and are more genetically stable (Koprek et al. 2001; Nagaya et al. 2005). Consequently, in commercial transformation, only plants that possess a single copy of all transgenes, and that are free of $A$. tumefaciens backbone sequences, based on quantitative polymerase chain reaction (qPCR) analyses, are advanced to phenotypic analysis and subsequent seed production. Single-copy transgenic events (SCEs) without any backbone sequences, outside the T-DNA left and right borders, are referred to as "single-copy events."

In this study, a design of experiment (DoE) approach was utilized to examine parameters that affect plant regeneration and healthy root. Design of experiment is a statistical methodology that allows simultaneous testing of multiple factors to understand and improve complex systems (Condra 2001; Niedz and Evens 2016).

Nitrogen $(\mathrm{N})$ is an essential plant macronutrient required for the synthesis of proteins and nucleic acids. In aqueous media, nitrogen is available to plants in the form of the nitrate ion and reduced in the form of the ammonium ion (George et al. 2008). The amount and form of $\mathrm{N}$ in tissue culture media has significant effects on cell growth and differentiation (Ramage and Williams 2002). In plant tissue culture media, $\mathrm{N}$ is supplied in various salts and varying the salts creates the 


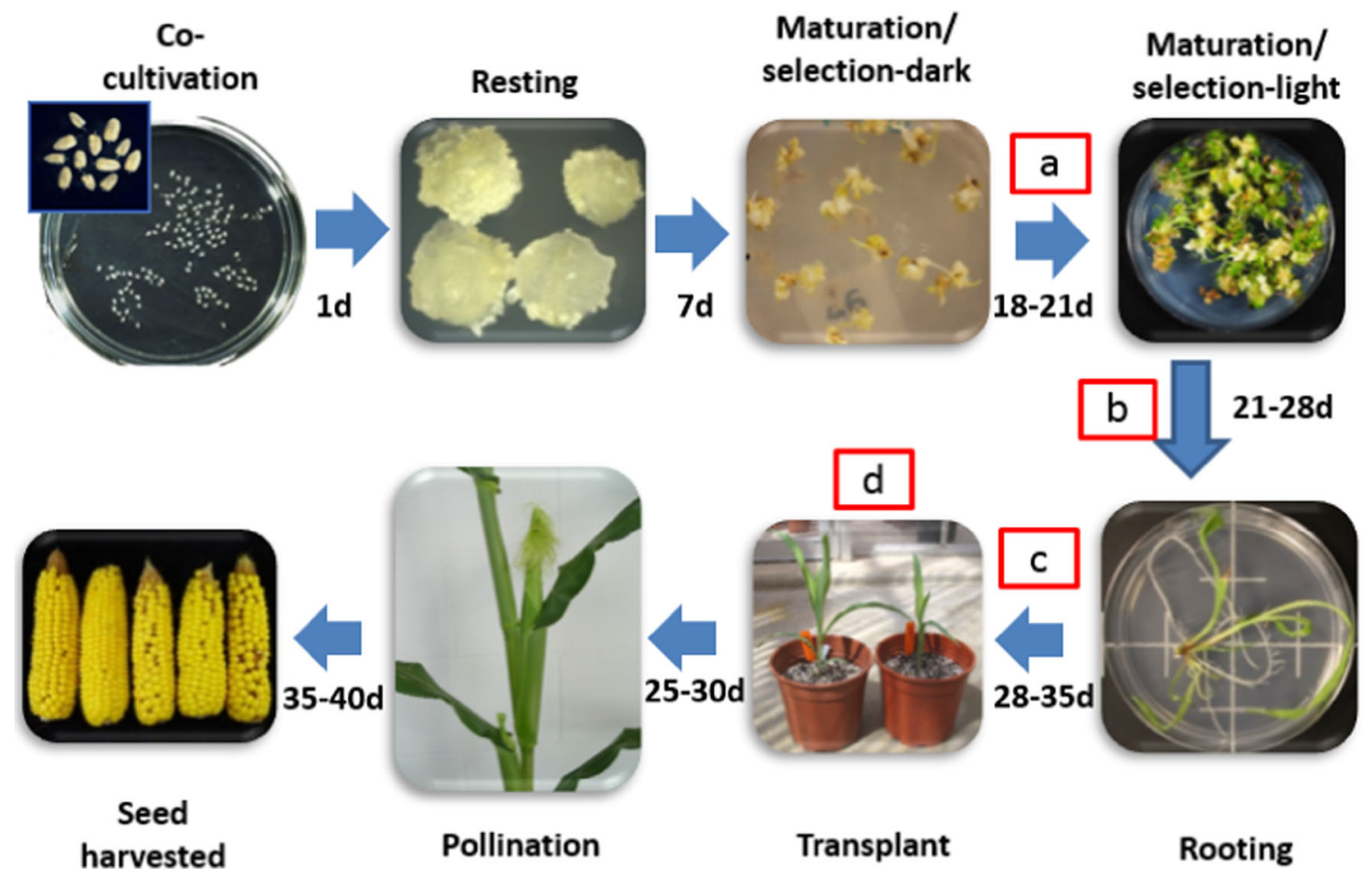

Fig. 2 New transformation methodprocess total elapsed time is 117 to $138 \mathrm{~d}$. The process starts with isolating Zea mays L. immature zygotic embryos and infecting with Agrobacterium tumefaciens. Distinct, individual somatic embryos form directly from the scutellum of the zygotic embryo and without callus formation. Somatic embryos develop on maturation/selection for 21-25 $\mathrm{d}$ and are directly germinated

problem of ion confounding between the effect of the Nsource, and the counter ion in that salt. Varying the ratio of $\mathrm{NH}_{4}{ }^{+} / \mathrm{K}^{+}$and the total nitrate concentration $\left[\mathrm{NO}_{3}{ }^{-}\right]$in a twocomponent mixture, provided a direct estimation of mineral nutrient effects without the ion confounding of a salt-based approach (Niedz and Evens 2008). Potassium nutrition was also considered in this design. In cereal tissue culture, Murashige and Skoog (MS; Murashige and Skoog 1962) medium is commonly used as the basal medium for plant regeneration (Gordon-Kamm et al. 1990; Frame et al. 2002), and it contains a ratio of $\mathrm{NH}_{4}{ }^{+} / \mathrm{K}^{+}$cations that is approximately 1 .

The duration and intensity of light can have a significant impact on embryo maturation and germination (Kintzios et al. 1998). This is particularly true for maize, a C4 plant that thrives in a high light environment.

For maize plant tissue culture, plant regeneration occurs either through organogenesis (Springer et al. 1979) or embryogenesis (Green 1982). The regeneration pathway is dictated by the type and relative concentrations of plant growth regulators (PGRs) in the medium or by the expression of morphogenic genes such as WUS2 and BBM. The process described in this paper utilized a morphogenic gene-stimulated, direct embryogenesis pathway. Plant growth regulators are used to improve performance of embryo maturation. The weak auxin indole-3butyric acid (IBA) was used to promote root development. The

into plants starting $1 \mathrm{mo}$ after infection. Following germination and an additional rooting step, plants are sent to the $\mathrm{GH}$ for transplanting into soil. Transplanted T0 plantlets are grown to maturity, pollinated, and seed is harvested after approximately 3 to 4 mo. Letters $a, b, c$, and $d$ represent data collection time points in the process

purine-based cytokinins, zeatin, and 6-benzylaminopurine (BAP) and the synthetic substituted urea, thidiazuron (TDZ), were included to promote plantlet development. Abscisic acid (ABA) was also included to prevent precocious germination and to promote embryo maturation (White et al. 2000).

A DoE approach was used to explore the relationship between multiple factors in the new, rapid culture method on the process outcomes. Design of experiment experimental design is particularly useful to observe interactions among factors that are not predicted with experiments designed to test a one factor at a time (OFAT). Ten parameters in this complex system were tested, and they were classified as nitrogen form and nitrate concentration, PGR, and light (L) conditions. Factors that influence root development and overall health of germinating somatic embryos included different amounts, ratios, and sources of N, IBA, zeatin, BAP, TDZ, ABA, and the duration and intensity of light.

\section{Materials and Methods}

Donor material and tissue culture Maize seed was sown at a 2.5 -cm depth into 32-cell flats $(90.7 \mathrm{~mL}$ individual cell volume), containing a substrate composed of $(v / v / v) 77 \%$ Canadian sphagnum peat, $16 \%$ perlite, and $7 \%$ vermiculite 
and adjusted with lime to a $\mathrm{pH}$ of 6.1 . Flats were irrigated with municipal water supplemented with $125 \mathrm{mg} \mathrm{L}^{-1} \mathrm{~N}$ from Peters Excel® 15-5-15 (ICL Specialty Fertilizers, Dublin, $\mathrm{OH})$.

Seeds were germinated and grown in a greenhouse $(\mathrm{GH})$ at temperature set-points of $25.5^{\circ} \mathrm{C}$ day $20.0^{\circ} \mathrm{C}$ night and $16 \mathrm{~h}$ daylight. After $21 \mathrm{~d}$, seedlings were transplanted into $5.9 \mathrm{~L}$ pots containing a soilless substrate composed of $(v / v / v / v) 38 \%$ Canadian sphagnum peat, $51 \%$ composted bark, $8 \%$ perlite, and $3 \%$ vermiculite and adjusted with lime to a $\mathrm{pH}$ of 6.0. After transplant, the plants were irrigated with municipal water supplemented with $95 \mathrm{mg} \mathrm{L}^{-1} \mathrm{~N}$ with the fertilizer.

Maize ears from the Pioneer inbred line HC69 were collected from the GH (Johnston, IA) at 10 to $11 \mathrm{~d}$ after pollination, when the immature embryos were between 1.6 and $1.8 \mathrm{~mm}$ in length. Ears were sterilized with $20 \%(v / v)$ Clorox ${ }^{\circledR}$ (final concentration of sodium hypochlorite of $1.65 \%$ ) for $15 \mathrm{~min}$ and rinsed three times with sterile distilled water. Immature embryos, $1.6-1.8 \mathrm{~mm}$ in length, were extracted intact from these ears, and were placed directly into $700 \mathrm{~A}$ liquid medium (Table 1) prior to transformation. To eliminate ear-to-ear variation in embryo response, the embryos for each treatment were randomly selected from among 20 ears.

Agrobacterium tumefaciens strain and plasmid vectors A. tumefaciens strain LBA4404Thy- (Ranch et al. 2012) containing an accessory plasmid (Anand et al. 2018) was used to transform the immature maize embryos containing vector PHP81814 (Fig. 3). PHP81814 was designed to ensure that only transformed plants with excised $B B M$ and WUS2 could regenerate. The double mutant of the endogenous acetolactate synthase gene (HRA) gene provides resistance to imidazolinones and sulfonylureas (Green et al. 2009) and does not contain any introns. The potato LS1 intron (Eckes et al. 1986) was modified by the insertion of a LoxP recombination site, and this synthetic intron was placed into the $H R A$ gene to divide and inactivate the $H R A$ gene into two synthetic exons. The resulting intron within the modified $H R A$ gene splices normally and is fully functional. Briefly, PHP81814 consists of, from right border to left border, the first synthetic

Table 1 Formulation for different media used in the new maize transformation method

\begin{tabular}{|c|c|c|c|}
\hline Steps & Medium name & Medium base & Ingredient \\
\hline Master plate & $12 \mathrm{R}$ & $\mathrm{AB}^{\mathrm{a}}$ & $\begin{array}{l}\text { AB salts, } 5 \mathrm{~g} \mathrm{~L}^{-1} \text { glucose, } 50 \mathrm{mg} \mathrm{L}^{-1} \text { spectinomycin, } \\
50 \mathrm{mg} \mathrm{L}^{-1} \text { thymidine, } 50 \mathrm{mg} \mathrm{L}^{-1} \text { gentamicin }\end{array}$ \\
\hline Working plate & $810 \mathrm{~K}$ & $\mathrm{YP}^{\mathrm{b}}$ & $\begin{array}{l}5 \mathrm{~g} \mathrm{~L}^{-1} \text { sodium chloride, } 5 \mathrm{~g} \mathrm{~L}^{-1} \text { yeast extract, } \\
10 \mathrm{~g} \mathrm{~L}^{-1} \text { peptone, } 50 \mathrm{mg} \mathrm{L}^{-1} \text { spectinomycin, } \\
50 \mathrm{mg} \mathrm{L}^{-1} \text { thymidine and } 50 \mathrm{mg} \mathrm{L}^{-1} \text { gentamicin }\end{array}$ \\
\hline Infection & $700 \mathrm{~A}$ & $\mathrm{MS}^{\mathrm{cg}}$ & $\begin{array}{l}68.5 \mathrm{~g} \mathrm{~L}^{-1} \text { sucrose, } 36 \mathrm{~g} \mathrm{~L}^{-1} \text { glucose, } \\
1.5 \mathrm{mg} \mathrm{L}^{-1} 2,4-\mathrm{D}, \mathrm{pH} 5.8\end{array}$ \\
\hline Co-cultivation & 710I & MS & $\begin{array}{l}20 \mathrm{~g} \mathrm{~L}^{-1} \text { sucrose, } 10 \mathrm{~g} \mathrm{~L}^{-1} \text { glucose, } 2.0 \mathrm{mg} \mathrm{L}^{-1} 2,4-\mathrm{D}, \\
100 \mu \mathrm{M} \text { acetosyringone, } 50 \mathrm{mg} \mathrm{L}^{-1} \text { thymidine, } \mathrm{pH} 5.8\end{array}$ \\
\hline Resting & $605 \mathrm{G}$ & $\mathrm{MS}+\mathrm{N} 6^{\mathrm{d}}$ & $\begin{array}{l}\text { MS salts, } 0.6 \mathrm{X} \mathrm{N6} \text { macro salts, } 1.68 \mathrm{~g} \mathrm{~L}^{-1} \text { potassium nitrate, } \\
\text { 0.6X B5 minor salts, } 0.4 \mathrm{X} \text { Eriksson's vitamins } \\
\text { e.6X S\&H vitamins } \\
\text { fg }, 0.2 \mathrm{mg} \mathrm{L}^{-1} \text { thiamine } \\
0.3 \mathrm{~g} \mathrm{~L}^{-1} \text { casein hydrolysate, } 20 \mathrm{~g} \mathrm{~L}^{-1} \text { sucrose, } \\
2 \mathrm{~g} \mathrm{~L}^{-1} \text { proline } \mathrm{g}^{\mathrm{g}}, 0.6 \mathrm{~g} \mathrm{~L}^{-1} \text { glucose, } \\
0.8 \mathrm{mg} \mathrm{L}^{-1} 2,4-\mathrm{D}, 1.2 \mathrm{mg} \mathrm{L}^{-1} \text { dicamba, }^{-1} \\
100 \mathrm{mg} \mathrm{L}^{-1} \text { carbenicillin and } 10 \mathrm{mg} \mathrm{L}^{-1} \text { meropenem }^{\mathrm{h}} \text {, } \\
\text { pH } 5.8\end{array}$ \\
\hline Maturation & 13329 & MS & $\begin{array}{l}1.25 \mathrm{mg} \mathrm{L}^{-1} \mathrm{CuSO}_{4}, 0.1 \mathrm{mg} \mathrm{L}^{-1} \text { imazapyr, } \\
\text { no PPT, 0.1 } \mu \mathrm{MABA}, 0.455 \mu \mathrm{M} \text { TDZ, } 4.44 \mu \mathrm{M} \text { BAP, } \\
2.28 \mu \mathrm{M} \text { zeatin, } 8 \% \text { Sigma agar }{ }^{\mathrm{TM}}, \mathrm{pH} 5.8\end{array}$ \\
\hline Rooting & $13158 \mathrm{I}$ & MS & $\begin{array}{l}40 \mathrm{~g} \mathrm{~L}^{-1} \text { sucrose, hormone free, } 100 \mathrm{mg} \mathrm{L}^{-1} \text { benomyl, } \\
\mathrm{pH} 5.8\end{array}$ \\
\hline
\end{tabular}

${ }^{\mathrm{a}} \mathrm{AB}$ medium (Chilton et al. 1974)

${ }^{\mathrm{b}}$ YP medium $1 \%$ Bacto® yeast extract, $2 \%$ Bacto® peptone, and $2 \%$ Bacto ${ }^{\circledR}$ agar (Difco, Franklin Lakes, NJ USA)

${ }^{\mathrm{c}}$ MS medium (Murashige and Skoog 1962)

${ }^{\mathrm{d}} \mathrm{N} 6$ medium (Chu et al. 1975)

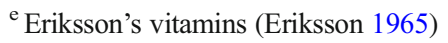

${ }^{\mathrm{f}}$ Schenk and Hildebrandt vitamins (Schenk and Hildebrandt 1972)

${ }^{g}$ Phytotech Labs (Shawnee Mission, KS, USA)

${ }^{\mathrm{h}}$ Carbosynth (Berkshire, England) 
Fig. 3 PHP81814 vector map

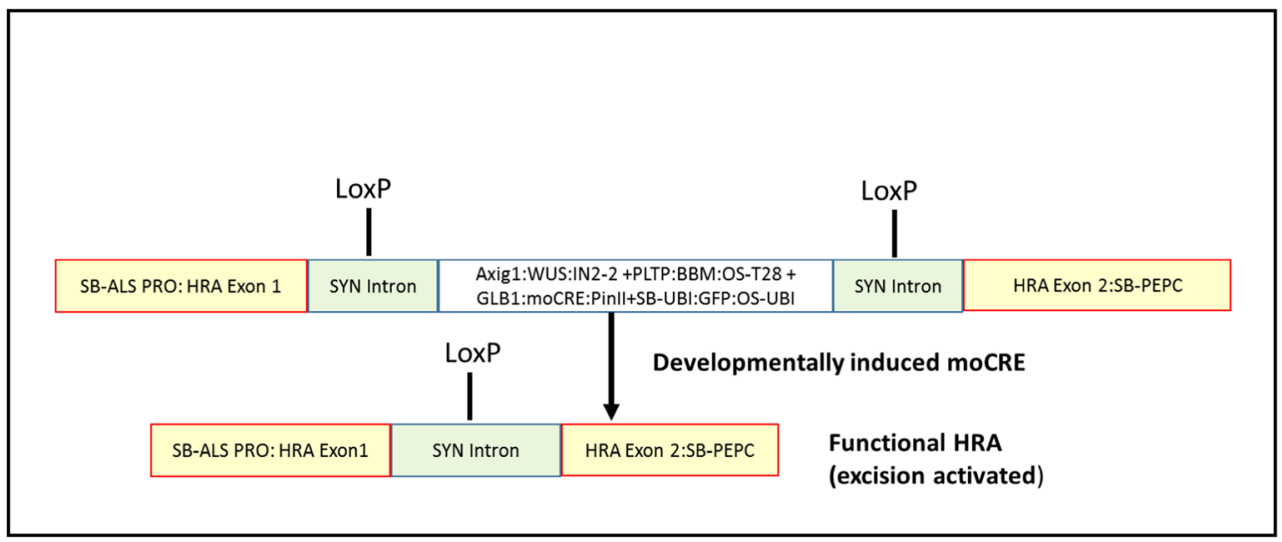

exon of the $H R A$ gene, followed by the synthetic intron containing the embedded LoxP site. Following the intron are expression cassettes for the two transcription factors WUS2 and $B B M$, followed by moCRE and GFP cassettes, a repeat of the synthetic intron with an embedded LoxP site, followed by the second synthetic exon of the HRA gene and Sb-PEPC terminator. The moCRE recombinase was used to remove all of the sequences between the LoxP sites (WUS2, BBM, moCRE, and $G F P$ ). MoCRE recombinase expression is driven by the maize globulin1 (GLB1) promoter that becomes active during later embryo development (Belanger and Kriz 1991). Upon moCRE-mediated excision, the two halves of the HRA gene are reconstituted creating a functional gene with a single LoxP-containing intron, such that only excised transformation events confer herbicide resistance. Using this system, only plants that have excised at least one copy of the $B B M$ and WUS 2 cassettes can regenerate under selective pressure. The auxin inducible promoter Axig1 (Garnaat et al. 2005) was used to drive WUS2 expression, and a Phospholipid Transfer Protein promoter (ZM-PLTP) was used to drive BBM. The ZM-PLTP promoter expresses in callus, cultured embryos, and in a subset of leaf epidermal cells but is not expressed in roots, meristems, and reproductive tissues (Lowe et al. 2018).

Immature embryo infection and agrobacterium transformation A thymidine auxotrophic strain of A. tumefaciens (LBA4404 Thy) containing an accessory plasmid (Anand et al. 2018) and plasmids described above were grown for $1 \mathrm{~d}$ on $810 \mathrm{~K}$ medium at $28^{\circ} \mathrm{C}$ (Table 1 ), and growing colonies were collected and suspended in 700A liquid medium with an optical density $\left(\mathrm{OD}_{550}\right)$ of 0.4 . Immature zygotic embryos were isolated from 20 ears and placed in 700A medium containing A. tumefaciens for $5 \mathrm{~min}$. The embryos were removed from the medium and placed scutellum side up on 710I solid medium for $1 \mathrm{~d}$ at $21^{\circ} \mathrm{C}$ in the dark (see Table 1 for all media formulations). Next, the immature zygotic embryos were moved to resting medium $605 \mathrm{G}$ and cultured for $1 \mathrm{wk}$. After 1 wk on $605 \mathrm{G}$, abundant numbers of somatic embryos were observed to be proliferating from the zygotic embryo scutellar surfaces, and only those zygotic embryos were moved to the test media. All chemicals were purchased from Sigma Aldrich® (St Louis, MO) unless otherwise noted.

Treatment factors and their combinations The DOE Custom design JMP 12 software (SAS institute, Cary, NC) d-optimal criteria for 10 continuous variables (Table 2), selected 73 model points from 59,049 possible media and process combinations. One model point was duplicated (treatments 44, 45), and the control process was included (treatment 75, Table 3). The MS-based control maturation medium 13329 was used as the control, and it contained $0.1 \mu \mathrm{M}$ ABA, $0.45 \mu \mathrm{M}$ TDZ, $4.44 \mu \mathrm{M}$ BAP, and $2.28 \mu \mathrm{M}$ zeatin. The ratio of ammonium $\left(\mathrm{NH}_{4}{ }^{+}\right)$to potassium $\left(\mathrm{K}^{+}\right)$was 1 , and the total nitrate concentration was $40 \mathrm{mM}$ (Table 3). Duration of exposure to light was $7 \mathrm{~d}$ under cool white fluorescent lamps (GE Ecolux, Boston, MA) at 60 to $70 \mu \mathrm{mol} \mathrm{m} \mathrm{m}^{-2}$. The zygotic embryos with somatic embryos were randomized and transferred to 73 different modified 13329 media and the control. One of the 73 modified media was replicated for a total of 74 treatments plus the control. Each treatment had three plates, with 10 embryos per plate. The entire experiment was done once. The DoE design included internal replication within the multidimensional design space. The cultured zygotic embryos with protruding somatic embryos, stayed on modified 13329 media for $11 \mathrm{~d}$ in the dark, after which they were moved to light-emitting diode (LED) lighting (Conviron $\AA$, Winnipeg, Canada), with different light intensities and different light durations. Plantlets were moved to rooting medium 13158I after the specified duration of exposure to light (Table 3). After a total of $14 \mathrm{~d}$ on $13158 \mathrm{I}$, rooted plants were sent to the $\mathrm{GH}$.

Nitrogen form and concentration Historically, in cereal tissue culture, MS medium has been commonly used for plant regeneration and it contains a $\mathrm{NH}_{4}^{+} / \mathrm{K}^{+}$ratio of 1 . For this experiment, the two-component mixture of $\mathrm{NH}_{4}{ }^{+}$and $\mathrm{K}^{+}$and one quantitative factor $\mathrm{NO}_{3}{ }^{-}$amount were tested using a mixture amount design similar to Niedz and Evens (2008). Factor levels are shown in Table 2. 
Table 2 Treatment factors and ranges tested in the design of experiment (DoE)

\begin{tabular}{|c|c|c|c|c|c|c|}
\hline Code & Factors & Unit & Current level & Low & Medium & High \\
\hline$\stackrel{\mathrm{N}-}{\text { nitrogen }}$ & Ratio of $\mathrm{NH}_{4}^{+} / \mathrm{K}^{+}$ & None & 1 & 0 & 0.333 & 1 \\
\hline $\mathrm{N}_{\text {nitrogen }}$ & {$\left[\mathrm{NO}_{3}{ }^{-}\right]$} & $\mathrm{mM}$ & 40 & 20 & 40 & 60 \\
\hline L-light & Duration of light treatment & day & 10 & 3 & 10 & 17 \\
\hline $\mathrm{L}$-light & Light intensity & $\mu \mathrm{mol} \mathrm{m}{ }^{-2} \mathrm{~s}^{-1}$ & $60-70$ & 50 & 150 & 250 \\
\hline $\mathrm{P}-\mathrm{PGR}$ & IBA overlay-duration & day & NA & 0 (no overlay) & 5 & 10 \\
\hline $\mathrm{P}-\mathrm{PGR}$ & IBA overlay-concentration & $\mu \mathrm{M}$ & NA & 0 (water control) & 2.46 & 9.85 \\
\hline $\mathrm{P}-\mathrm{PGR}$ & $\mathrm{ABA}$ & $\mu \mathrm{M}$ & 0.1 & 0 & 0.1 & 1 \\
\hline $\mathrm{P}-\mathrm{PGR}$ & TDZ & $\mu \mathrm{M}$ & 0.455 & 0 & 0.145 & 0.455 \\
\hline $\mathrm{P}-\mathrm{PGR}$ & BAP & $\mu \mathrm{M}$ & 4.44 & 0 & 1.42 & 14.2 \\
\hline $\mathrm{P}-\mathrm{PGR}$ & Zeatin & $\mu \mathrm{M}$ & 2.28 & 0 & 1.46 & 14.6 \\
\hline
\end{tabular}

Factors were categorized as nutrient $(\mathrm{N})$, light $(\mathrm{L})$, or plant growth regulator $(\mathrm{P})$

$A B A$, abscisic acid; $B A P$, 6-benzylaminopurine; $I B A$, indole-3-acetic acid; $T D Z$, thidiazuron; $\mathrm{NH}_{4}^{+} / \mathrm{K}^{+}$, ratio of $\left[\mathrm{NH}_{4}^{+}\right]$to $\left[\mathrm{K}^{+}\right]$; $\left[N O_{3}^{-}\right]$, nitrate concentration

Light intensity and duration The duration of exposure to light and the light intensity during the maturation step are shown in Table 2. For the light treatment, LED lighting at a 2:1 red to blue ratio was used.

Plant growth regulators Five growth regulators from three hormone families that are involved in meristem formation, embryo development, and root growth were tested at ranges shown in Table 2. Rooting factors included the application of a liquid solution of IBA of different concentrations that was layered over the media with the cultured embryos growing on $35 \mathrm{~mL}$ of 13329 maturation medium according to the schedule on Table 2 (referred to as an overlay treatment).

Data collection Response data at each design point were collected and used for modeling. The initial tissue morphology response of transformed zygotic embryos to the different media treatments was recorded after $11 \mathrm{~d}$ on maturation medium in the dark (Fig. 2, step a). A three-tiered scale was used to score the quality of the response; $1=$ no shoot formation (Fig. $4 a$ ), $2=$ tissue initiating small shoots with the potential to regenerate (Fig. 4b), and $3=$ regenerating tissue with visible shoots (Fig. $4 c$ ). Plantlets with green leafy shoots were counted and transferred to rooting medium (13158I) 2 wk prior to sending to the greenhouse (GH; Fig. 2, step b). Plants that had shoots longer than $1 \mathrm{~cm}$ and secondary roots were counted and sent to the $\mathrm{GH}$ (Fig. 2, step c). Each plant in the GH was specified as a T0 plant, and their survival after $28 \mathrm{~d}$ was recorded. Leaf samples were acquired while plants were in GH flats and samples were submitted for quantitative polymerase chain reaction (qPCR) analysis as described by Ingham et al. (2001), to determine the presence and copy number of the selectable marker, the leftand right-border regions, and presence of A. tumefaciens backbone sequences (Fig. 2, step d). Single-copy events were identified and the percentage of SCE frequency was calculated as SCE\% (SCE - T0s). Single-copy events were further analyzed by Southern-by-Sequencing ${ }^{\mathrm{TM}}$ (SBS ${ }^{\mathrm{TM}}$ ) as described by Zastrow-Hayes et al. (2015), to identify perfect insertion events without endogenous gene interruption. The percentage of final events (FE\%) was calculated based on starting zygotic embryos (SCE $\div$ starting zygotic embryos).

Statistical analysis A response surface model (RSM) was used to fit linear, second-order interactions, and simple quadratic terms. Forward stepwise model building techniques $(P$ value threshold with probability to enter $=0.25$ and probability to leave $=0.1$ ) eliminated terms to improve the utility of the final model assessed by a combination of the following criteria: the $\mathrm{R}$-squared value and the R-squared adjusted value for models, $F$-statistic, and probability $>F$. Lack of fit was found to be insignificant for all presented models.

Selected significant responses were plotted to visualize factors and interactions for important responses. Two important response models, the percent of plants sent to the $\mathrm{GH}$ and SCE\% models, were harmonized following stepwise elimination by combining any term that was significant in either. Maximal desirability functions were used when the models were fit together.

Validation experiment A validation experiment was executed using HC69 with the same vector, PHP81814. The experiment included four treatments: (A) a treatment designed to get a high percentage of plants sent to the $\mathrm{GH}$; (B) a treatment designed to get a high percentage of SCE; (C) a harmonized treatment designed for both; and (D) a control treatment at the current condition (Table 4). While the design for optimal light intensity for treatment A utilized LED lighting at $135 \mu \mathrm{mol} \mathrm{m} \mathrm{m}^{-2} \mathrm{~s}^{-1}$, the validation experiment was conducted 
Table 3 Treatment factors combinations selected by d-optimal criteria used in Design of Experiment (DoE) experiment

\begin{tabular}{|c|c|c|c|c|c|c|c|c|c|c|}
\hline Run & $\begin{array}{l}\text { Duration of exposure } \\
\text { to light }\end{array}$ & $\begin{array}{l}\text { Light intensity } \\
\left(\mu \mathrm{mol} \mathrm{m} \mathrm{m}^{-2} \mathrm{~s}^{-1}\right)\end{array}$ & $\begin{array}{l}\text { IBA conc } \\
(\mu \mathrm{M})\end{array}$ & $\begin{array}{l}\text { IBA overlay } \\
\text { duration (day) }\end{array}$ & $\begin{array}{l}\mathrm{ABA} \\
(\mu \mathrm{M})\end{array}$ & $\begin{array}{l}\text { TDZ } \\
(\mu \mathrm{M})\end{array}$ & $\begin{array}{l}\text { BAP } \\
(\mu \mathrm{M})\end{array}$ & $\begin{array}{l}\text { Zeatin } \\
(\mu \mathrm{M})\end{array}$ & $\begin{array}{l}\mathrm{NH}_{4}^{+} / \\
\mathrm{K}^{+}\end{array}$ & $\begin{array}{l}{\left[\mathrm{NO}_{3}^{-}\right]} \\
(\mathrm{mM})\end{array}$ \\
\hline 1 & 3 & 250 & 9.85 & 5 & 1 & 0.455 & 0 & 0 & 0 & 20 \\
\hline 2 & 3 & 50 & 2.46 & 0 & 0 & 0.145 & 0 & 0 & 0 & 20 \\
\hline 3 & 3 & 150 & 0 & 10 & 1 & 0 & 0 & 14.6 & 0 & 20 \\
\hline 4 & 10 & 50 & 9.85 & 10 & 0 & 0 & 14.2 & 0 & 0 & 20 \\
\hline 5 & 17 & 50 & 9.85 & 0 & 1 & 0 & 0 & 14.6 & 0 & 20 \\
\hline 6 & 3 & 150 & 0 & 10 & 0 & 0.455 & 14.2 & 1.46 & 0 & 20 \\
\hline 7 & 17 & 250 & 9.85 & 0 & 0 & 0.455 & 14.2 & 14.6 & 0 & 20 \\
\hline 8 & 3 & 250 & 0 & 10 & 1 & 0 & 14.2 & 1.46 & 0 & 20 \\
\hline 9 & 10 & 150 & 9.85 & 0 & 0 & 0.455 & 1.42 & 0 & 0 & 20 \\
\hline 10 & 10 & 250 & 2.46 & 10 & 0 & 0.145 & 1.42 & 14.6 & 0 & 20 \\
\hline 11 & 10 & 50 & 0 & 5 & 1 & 0.455 & 14.2 & 0 & 0 & 20 \\
\hline 12 & 17 & 50 & 2.46 & 5 & 0.1 & 0.455 & 1.42 & 1.46 & 0 & 40 \\
\hline 13 & 17 & 150 & 0 & 0 & 1 & 0.145 & 14.2 & 14.6 & 0 & 40 \\
\hline 14 & 3 & 150 & 2.46 & 0 & 0 & 0 & 14.2 & 14.6 & 0 & 40 \\
\hline 15 & 3 & 50 & 9.85 & 10 & 1 & 0.145 & 14.2 & 14.6 & 0 & 40 \\
\hline 16 & 17 & 250 & 9.85 & 0 & 0.1 & 0.145 & 0 & 1.46 & 0 & 40 \\
\hline 17 & 17 & 50 & 2.46 & 5 & 0.1 & 0.455 & 1.42 & 1.46 & 0 & 40 \\
\hline 18 & 10 & 250 & 0 & 5 & 0 & 0 & 0 & 0 & 0 & 40 \\
\hline 19 & 17 & 150 & 9.85 & 0 & 0 & 0 & 1.42 & 14.6 & 0 & 60 \\
\hline 20 & 3 & 250 & 9.85 & 10 & 0 & 0 & 0 & 1.46 & 0 & 60 \\
\hline 21 & 3 & 150 & 9.85 & 0 & 0.1 & 0.455 & 0 & 14.6 & 0 & 60 \\
\hline 22 & 3 & 250 & 0 & 10 & 1 & 0.455 & 1.42 & 14.6 & 0 & 60 \\
\hline 23 & 17 & 150 & 0 & 10 & 1 & 0.145 & 0 & 0 & 0 & 60 \\
\hline 24 & 17 & 50 & 0 & 0 & 0 & 0.455 & 14.2 & 0 & 0 & 60 \\
\hline 25 & 17 & 250 & 9.85 & 10 & 0.1 & 0.455 & 14.2 & 0 & 0 & 60 \\
\hline 26 & 3 & 250 & 0 & 0 & 1 & 0 & 0 & 0 & 0 & 60 \\
\hline 27 & 3 & 50 & 0 & 10 & 0.1 & 0 & 1.42 & 0 & 0 & 60 \\
\hline 28 & 10 & 250 & 0 & 0 & 0.1 & 0.455 & 14.2 & 1.46 & 0.333 & 20 \\
\hline 29 & 17 & 50 & 0 & 10 & 0 & 0.455 & 0 & 0 & 0.333 & 20 \\
\hline 30 & 3 & 50 & 9.85 & 0 & 1 & 0 & 1.42 & 1.46 & 0.333 & 20 \\
\hline 31 & 17 & 150 & 0 & 0 & 0.1 & 0 & 1.42 & 0 & 0.333 & 20 \\
\hline 32 & 17 & 150 & 2.46 & 10 & 1 & 0.455 & 14.2 & 14.6 & 0.333 & 20 \\
\hline 33 & 10 & 150 & 2.46 & 5 & 0.1 & 0.145 & 1.42 & 1.46 & 0.333 & 40 \\
\hline 34 & 17 & 50 & 9.85 & 5 & 0 & 0.455 & 0 & 14.6 & 0.333 & 40 \\
\hline 35 & 10 & 150 & 2.46 & 10 & 1 & 0.145 & 1.42 & 0 & 0.333 & 40 \\
\hline 36 & 17 & 250 & 2.46 & 5 & 1 & 0 & 1.42 & 14.6 & 0.333 & 40 \\
\hline 37 & 10 & 150 & 2.46 & 10 & 1 & 0.145 & 1.42 & 0 & 0.333 & 40 \\
\hline 38 & 3 & 50 & 0 & 0 & 1 & 0.455 & 0 & 1.46 & 0.333 & 40 \\
\hline 39 & 3 & 250 & 9.85 & 0 & 0 & 0.145 & 14.2 & 0 & 0.333 & 60 \\
\hline 40 & 17 & 50 & 0 & 10 & 0.1 & 0 & 14.2 & 14.6 & 0.333 & 60 \\
\hline 41 & 10 & 150 & 2.46 & 5 & 0.1 & 0.145 & 14.2 & 1.46 & 0.333 & 60 \\
\hline 42 & 17 & 50 & 9.85 & 0 & 1 & 0.455 & 1.42 & 14.6 & 0.333 & 60 \\
\hline 43 & 17 & 50 & 9.85 & 0 & 1 & 0 & 14.2 & 0 & 0.333 & 60 \\
\hline 44 & 10 & 50 & 9.85 & 5 & 0.1 & 0.145 & 0 & 0 & 0.333 & 60 \\
\hline 45 & 10 & 50 & 9.85 & 5 & 0.1 & 0.145 & 0 & 0 & 0.333 & 60 \\
\hline 46 & 17 & 50 & 9.85 & 0 & 1 & 0.455 & 1.42 & 14.6 & 0.333 & 60 \\
\hline 47 & 3 & 250 & 0 & 5 & 0 & 0.145 & 0 & 14.6 & 0.333 & 60 \\
\hline 48 & 10 & 150 & 2.46 & 5 & 0.1 & 0.145 & 14.2 & 1.46 & 0.333 & 60 \\
\hline
\end{tabular}


Table 3 (continued)

\begin{tabular}{|c|c|c|c|c|c|c|c|c|c|c|}
\hline Run & $\begin{array}{l}\text { Duration of exposure } \\
\text { to light }\end{array}$ & $\begin{array}{l}\text { Light intensity } \\
\left(\mu \mathrm{mol} \mathrm{m} \mathrm{m}^{-2} \mathrm{~s}^{-1}\right)\end{array}$ & $\begin{array}{l}\text { IBA conc } \\
(\mu \mathrm{M})\end{array}$ & $\begin{array}{l}\text { IBA overlay } \\
\text { duration (day) }\end{array}$ & $\begin{array}{l}\mathrm{ABA} \\
(\mu \mathrm{M})\end{array}$ & $\begin{array}{l}\text { TDZ } \\
(\mu \mathrm{M})\end{array}$ & $\begin{array}{l}\text { BAP } \\
(\mu \mathrm{M})\end{array}$ & $\begin{array}{l}\text { Zeatin } \\
(\mu \mathrm{M})\end{array}$ & $\begin{array}{l}\mathrm{NH}_{4}^{+} / \\
\mathrm{K}^{+}\end{array}$ & $\begin{array}{l}{\left[\mathrm{NO}_{3}^{-}\right]} \\
(\mathrm{mM})\end{array}$ \\
\hline 49 & 10 & 250 & 2.46 & 10 & 0 & 0.455 & 0 & 0 & 0.333 & 60 \\
\hline 50 & 10 & 250 & 9.85 & 10 & 0.1 & 0.455 & 14.2 & 1.46 & 1 & 20 \\
\hline 51 & 10 & 250 & 9.85 & 0 & 1 & 0 & 14.2 & 0 & 1 & 20 \\
\hline 52 & 3 & 50 & 2.46 & 10 & 0.1 & 0.455 & 0 & 14.6 & 1 & 20 \\
\hline 53 & 3 & 250 & 0 & 5 & 1 & 0.145 & 14.2 & 14.6 & 1 & 20 \\
\hline 54 & 17 & 250 & 2.46 & 5 & 0 & 0.145 & 14.2 & 0 & 1 & 20 \\
\hline 55 & 10 & 50 & 0 & 5 & 0 & 0 & 1.42 & 1.46 & 1 & 20 \\
\hline 56 & 17 & 50 & 9.85 & 10 & 1 & 0 & 0 & 0 & 1 & 20 \\
\hline 57 & 17 & 150 & 0 & 0 & 0.1 & 0.455 & 0 & 14.6 & 1 & 20 \\
\hline 58 & 3 & 250 & 9.85 & 0 & 0 & 0 & 0 & 1.46 & 1 & 20 \\
\hline 59 & 3 & 50 & 2.46 & 0 & 0 & 0.455 & 14.2 & 0 & 1 & 20 \\
\hline 60 & 17 & 250 & 0 & 10 & 1 & 0.145 & 0 & 1.46 & 1 & 20 \\
\hline 61 & 3 & 250 & 9.85 & 0 & 1 & 0.455 & 0 & 1.46 & 1 & 40 \\
\hline 62 & 17 & 150 & 2.46 & 10 & 0 & 0 & 0 & 14.6 & 1 & 40 \\
\hline 63 & 17 & 50 & 9.85 & 0 & 0.1 & 0.145 & 14.2 & 14.6 & 1 & 40 \\
\hline 64 & 3 & 150 & 0 & 5 & 0.1 & 0.145 & 1.42 & 0 & 1 & 40 \\
\hline 65 & 10 & 250 & 0 & 10 & 0 & 0.455 & 14.2 & 14.6 & 1 & 40 \\
\hline 66 & 10 & 50 & 2.46 & 0 & 1 & 0 & 0 & 14.6 & 1 & 60 \\
\hline 67 & 10 & 250 & 9.85 & 10 & 0.1 & 0 & 0 & 0 & 1 & 60 \\
\hline 68 & 17 & 250 & 0 & 0 & 1 & 0.455 & 1.42 & 0 & 1 & 60 \\
\hline 69 & 17 & 50 & 2.46 & 10 & 0 & 0.145 & 1.42 & 0 & 1 & 60 \\
\hline 70 & 17 & 150 & 9.85 & 10 & 1 & 0.145 & 1.42 & 14.6 & 1 & 60 \\
\hline 71 & 10 & 250 & 0 & 0 & 0 & 0 & 14.2 & 1.46 & 1 & 60 \\
\hline 72 & 3 & 50 & 9.85 & 10 & 1 & 0.455 & 14.2 & 0 & 1 & 60 \\
\hline 73 & 3 & 50 & 0 & 0 & 0 & 0.455 & 1.42 & 14.6 & 1 & 60 \\
\hline 74 & 3 & 50 & 9.85 & 10 & 0 & 0 & 14.2 & 14.6 & 1 & 60 \\
\hline $\begin{array}{l}\text { 75/ } \\
\text { con- } \\
\text { trol }\end{array}$ & 7 & 60 & 0 & 0 & 0.1 & 0.455 & 4.44 & 2.28 & 1 & 40 \\
\hline
\end{tabular}

$A B A$, abscisic acid; $B A P$, 6-benzylaminopurine; $I B A$, indole-3-acetic acid; $T D Z$, thidiazuron; $\mathrm{NH}_{4}^{+} / \mathrm{K}^{+}$, ratio of $\left[\mathrm{NH}_{4}^{+}\right]$to $\left[\mathrm{K}^{+}\right] ;\left[N O_{3}^{-}\right]$, nitrate concentration

under fluorescent light with $60 \mu \mathrm{mol} \mathrm{m} \mathrm{m}^{-2}$ for the practical reason that the current growth rooms were not fully equipped with LED lights. For replacement of the IBA overlay treatment, IBA was added to the medium to avoid the extra step of adding exogenous IBA overlay onto the medium. Each treatment had 100 embryos, with 10 embryos per plate, and the embryos were randomly distributed across four ears to avoid ear-to-ear variation.
Fig. 4 Zea mays L. tissue morphology score recorded after $11 \mathrm{~d}$ in the dark: (a) score of 1 is a regenerating tissue with no shoot formation; (b) score of 2 is regenerating tissue with a potential shoot; $(c)$ score of 3 is regenerating tissue with an obvious, healthy, shoot

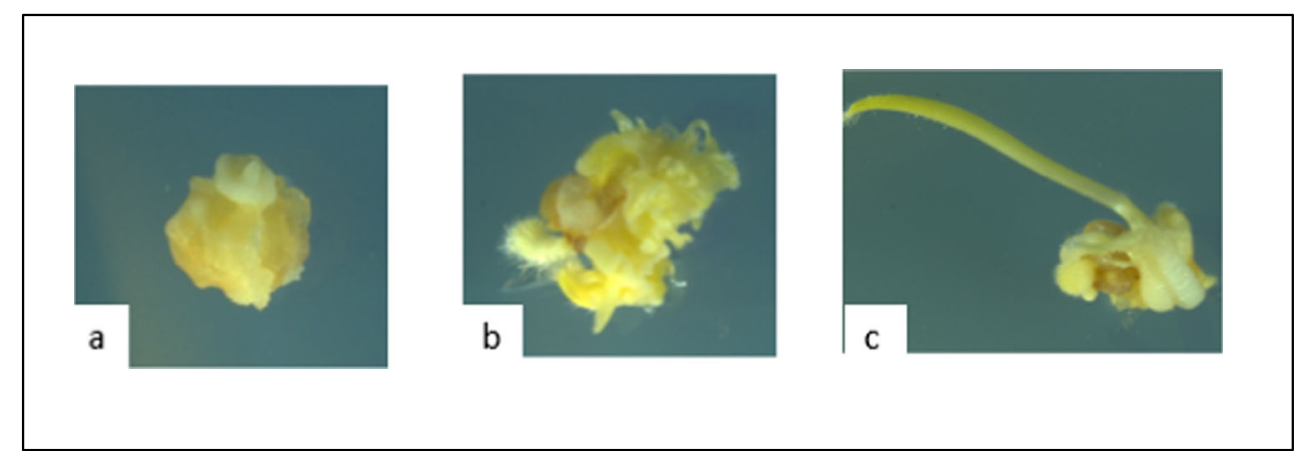


Table 4 Treatment factor combinations used in validation experiment

\begin{tabular}{lllllllll}
\hline Treatment & $\begin{array}{l}\mathrm{IBA} \\
\text { conc } \\
(\mu \mathrm{M})\end{array}$ & $\begin{array}{l}\mathrm{ABA} \\
(\mu \mathrm{M})\end{array}$ & $\begin{array}{l}\mathrm{TDZ} \\
(\mu \mathrm{M})\end{array}$ & $\begin{array}{l}\mathrm{BAP} \\
(\mu \mathrm{M})\end{array}$ & $\begin{array}{l}\mathrm{Zeatin} \\
(\mu \mathrm{M})\end{array}$ & $\begin{array}{l}\mathrm{NH}_{4}{ }^{+} / \\
\mathrm{K}^{+}\end{array}$ & $\mathrm{NO}_{3}{ }^{-}(\mathrm{mM})$ & $\begin{array}{l}\text { Duration of light } \\
\text { treatment (day) }\end{array}$ \\
\hline $\mathrm{A}$ & 2.92 & 1.00 & 0 & 7.10 & 0 & 0.6 & 40 & 5 \\
$\mathrm{~B}$ & 0 & 0 & 0 & 8.88 & 0 & 0.3 & 60 & 3 \\
$\mathrm{C}$ & 0 & 1.00 & 0 & 7.77 & 0.15 & 0.66 & 40 & 3 \\
Control & 0 & 0.10 & 0.45 & 4.44 & 2.28 & 1 & 40 & 10 \\
\hline
\end{tabular}

$A B A$, abscisic acid; $B A P$, 6-benzylaminopurine; $I B A$, indole-3-acetic acid; $T D Z$, thidiazuron; $\mathrm{NH}_{4}^{+} / \mathrm{K}^{+}$, ratio of $\left[\mathrm{NH}_{4}^{+}\right]$to $\left[\mathrm{K}^{+}\right] ;\left[\mathrm{NO}_{3}^{-}\right]$, nitrate concentration

\section{Results}

Many of the factors in the DoE design significantly impacted the responses measured during the progression from initiation of transformed tissue, through plantlet development to plants in the GH (Table 5; coded equations of model surfaces in Table S1). The two macronutrient factors, $\left[\mathrm{NO}_{3}{ }^{-}\right]$and $\mathrm{NH}_{4}{ }^{+} /$ $\mathrm{K}^{+}$ratio, were significant in every response, albeit with different optima. Factors that included PGRs and light were important in some but not all the responses. The transition of transformed tissue to plantlets that survived in the GH may be best promoted by a dynamic change in optimal treatment factor combinations. The abundance of SCEs could be better than the control, when utilizing processes selected from the 10 factors in the DoE for tissue morphology, shoots transferred to rooting, rooted plants sent to the $\mathrm{GH}$, and $\mathrm{T} 0$ plant survival in the $\mathrm{GH}$.

Ratio of $\mathrm{NH}_{4}^{+} / \mathrm{K}^{+}$and $\left[\mathrm{NO}_{3}{ }^{-}\right.$] effects on tissue morphology after $11 \mathrm{~d}$ on maturation medium Analysis of variance indicated that the $\left[\mathrm{NO}_{3}{ }^{-}\right]$and the ratio of $\mathrm{NH}_{4}{ }^{+} / \mathrm{K}^{+}$were highly significant $(P<0.0001)$ for tissue morphology at an early stage of embryo development (Table 5). Tissue growing on the control treatment (asterisk, Fig. 5), with the ratio of $\mathrm{NH}_{4}{ }^{+} /$ $\mathrm{K}^{+}$at 1 and $40 \mathrm{mM}\left[\mathrm{NO}_{3}{ }^{-}\right]$, was characterized by visually small, short, stunted shoots, dark brown tissue, and minimal growth (Fig. 4). Tissue growing on the control treatment was scored as a 2, as predicted by the model (Fig. $5 a$ ). When all other factors are set at optimal values (Fig. $5 b$ ), predicted data points moved toward the surface and the optimal control treatment moved onto the profile surface. The optimal setting for tissue morphology response was at a $\mathrm{NH}_{4}{ }^{+} / \mathrm{K}^{+}$ratio of 1 , regardless of the $\left[\mathrm{NO}_{3}{ }^{-}\right]$level. The control in Fig. $5 a$ was very far from the modeled optimal, even though macronutrient levels were near optimal, which indicated that other factors (PGRs, light, and their interactions) were less than optimal in the control setting.

BAP and ratio of $\mathrm{NH}_{4}^{+} / \mathrm{K}^{+}$effects on tissue morphology after $11 \mathrm{~d}$ on maturation medium The interaction between the ratio of $\mathrm{NH}_{4}{ }^{+} / \mathrm{K}^{+}$and BAP was very highly significant for tissue morphology. The optimal response was when the ratio of $\mathrm{NH}_{4}{ }^{+} / \mathrm{K}^{+}$was 1 (Fig. 6). At that ratio, the tissue morphology response improved linearly with increasing BAP concentrations to a maximal score of nearly 5 at $14.2 \mu \mathrm{M}$ BAP, much higher than the control value of $4.4 \mu \mathrm{M}$ BAP. As BAP is a growth regulator, these data indicated that BAP would have greatest positive effect when proper nutrients were supplied to support growth.

ABA and ratio of $\mathrm{NH}_{4}{ }^{+/} \mathrm{K}^{+}$effects on tissue morphology after $11 \mathrm{~d}$ on maturation medium Abscisic acid had a similar interaction to the ratio of $\mathrm{NH}_{4}{ }^{+} / \mathrm{K}^{+}$when the ratio of $\mathrm{NH}_{4}{ }^{+} / \mathrm{K}^{+}$ was at 1 (Fig. 7). Tissue morphology will be optimal when $\mathrm{ABA}$ is predicted to be at $0.7 \mu \mathrm{M}$, and any concentration of ABA greater or less than $0.7 \mu \mathrm{M}$ would be less desirable. This concentration of ABA was greater than the control value of $0.1 \mu \mathrm{M}$.

$A B A$ and BAP effects on tissue morphology after $11 \mathrm{~d}$ on maturation medium The interaction between BAP and ABA was a quadratic term with distinct values for an optimal response (Fig. 8). Increased BAP had the most pronounced effect on tissue morphology at moderate to high ABA levels $(0.4 \mu \mathrm{M}$ to $0.8 \mu \mathrm{M})$. Tissue morphology will be optimal at $0.7 \mu \mathrm{M}$ ABA and $14.2 \mu \mathrm{M}$ BAP.

Ratio of $\mathrm{NH}_{4}{ }^{+} \mathrm{K}^{+}$and light intensity effects on tissue morphology after $11 \mathrm{~d}$ on maturation medium Consistent with the other observations, the interaction between the ratio of $\mathrm{NH}_{4}{ }^{+} / \mathrm{K}^{+}$and light intensity was also optimal when the ratio of $\mathrm{NH}_{4}^{+} / \mathrm{K}^{+}$was at 1 (Fig. 9). The best tissue morphology score was at the lower light intensity of $50 \mu \mathrm{mol} \mathrm{m} \mathrm{m}^{-2}$ and less optimal results with increasing light intensity to $250 \mu \mathrm{mol} \mathrm{m} \mathrm{m}^{-2} \mathrm{~s}^{-1}$. The optimal values to obtain the highest tissue morphology scores were with the ratio of $\mathrm{NH}_{4}{ }^{+} / \mathrm{K}^{+}$at 1 , $0.7 \mu \mathrm{M}$ ABA, $14.2 \mu \mathrm{M}$ BAP, and $50 \mu \mathrm{mol} \mathrm{m}^{-2} \mathrm{~s}^{-1}$ light intensity.

Duration of exposure to light and light intensity effects on percentage of shoots to rooting There were fewer significant factors that promoted shoot tissue capable of root 
Table 5 Probability of significant factors determined by analysis of variance (ANOVA) for terms in responses for Zea mays L. tissue morphology, plants to rooting, plants sent to the greenhouse $(\mathrm{GH})$, survival of transformants in the $\mathrm{GH}$, and the number of single-copy events

\begin{tabular}{|c|c|c|c|c|c|c|}
\hline Code & Source & $\begin{array}{l}\text { Tissue morphology } \\
\text { score }\end{array}$ & $\begin{array}{l}\% \text { shoot to } \\
\text { rooting }\end{array}$ & $\begin{array}{l}\% \text { plant sent } \\
\text { to GH }\end{array}$ & $\begin{array}{l}\text { \#T0 } \\
\text { survived }\end{array}$ & $\% \mathrm{SCE}$ \\
\hline R-square & & 0.85 & 0.61 & 0.60 & 0.88 & 0.92 \\
\hline R-square-a & & 0.76 & 0.50 & 0.48 & 0.72 & 0.80 \\
\hline $\mathrm{N}$ & {$\left[\mathrm{NO}_{3}{ }^{-}\right]$} & -**** & & & -* & -**** \\
\hline $\mathrm{N}$ & {$\left[\mathrm{NO}_{3}^{-}\right] \bullet\left[\mathrm{NO}_{3}^{-}\right]$} & & -** & $-*$ & $-*$ & $-* *$ \\
\hline $\mathrm{N}$ & Ratio of $\mathrm{NH}_{4}^{+} / \mathrm{K}^{+}$ & $-* * * *$ & & $-* *$ & $-* *$ & $-* * * *$ \\
\hline $\mathrm{N}$ & Ratio of $\mathrm{NH}_{4}^{+} / \mathrm{K}^{+}$ratio of $\mathrm{NH}_{4}^{+} / \mathrm{K}^{+}$ & $-* * * *$ & & $-* *$ & $-* * *$ & \\
\hline $\mathrm{N}$ & Ratio of $\mathrm{NH}_{4}^{+} / \mathrm{K}^{+} \bullet\left[\mathrm{NO}_{3}{ }^{-}\right]$ & & & & $-*$ & $-* * * *$ \\
\hline $\mathrm{L}$ & Light intensity & & & & & \\
\hline $\mathrm{L}$ & Light intensity light intensity & & $-* *$ & & & \\
\hline $\mathrm{L}$ & Duration of light treatment & & & & & - ***** \\
\hline $\mathrm{L}$ & $\begin{array}{l}\text { Duration of light treatment duration of light } \\
\text { treatment }\end{array}$ & $-*$ & - **** & & $-* *$ & \\
\hline $\mathrm{L}$ & Duration of light treatment light intensity & & & & & \\
\hline$P$ & BAP & & -* & & & \\
\hline $\mathrm{P}$ & $\mathrm{BAP} \triangleleft \mathrm{BAP}$ & & & $-*$ & $-*$ & $-*$ \\
\hline $\mathrm{P}$ & TDZ & & & $-* *$ & $-* *$ & \\
\hline $\mathrm{P}$ & $\mathrm{TDZ} \bullet \mathrm{TDZ}$ & & & & $-* *$ & \\
\hline $\mathrm{P}$ & Zeatin & & & & & \\
\hline $\mathrm{P}$ & Zeatin zeatin & & & & & \\
\hline $\mathrm{P}$ & ABA & & & & & $-* *$ \\
\hline $\mathrm{P}$ & $\mathrm{ABA} \vee \mathrm{ABA}$ & & & & & \\
\hline $\mathrm{P}$ & IBA conc & $-*$ & & & & \\
\hline$P$ & IBA conc $\downarrow$ IBA conc & & & & $-*$ & \\
\hline$P$ & IBA overlay duration & $-* *$ & & & & \\
\hline$P$ & IBA overlay duration $\triangleleft$ IBA overlay duration & & & & $-* *$ & \\
\hline$P$ & BAP Zeatin & & & $-* *$ & $-* * *$ & \\
\hline$P$ & $\mathrm{BAP} \triangleleft \mathrm{TDZ}$ & & & & & - ***** \\
\hline $\mathrm{P}$ & $\mathrm{BAP} \triangleleft \mathrm{ABA}$ & $-* * *$ & & & & \\
\hline $\mathrm{P}$ & $\mathrm{BAP} \triangleleft \mathrm{IBA}$ conc & & & & & $-*$ \\
\hline $\mathrm{P}$ & BAP $\triangleleft$ IBA overlay duration & & & & & \\
\hline$P$ & TDZ Zeatin & & & & & $-* * * *$ \\
\hline$P$ & $\mathrm{TDZ} \bullet \mathrm{ABA}$ & & & & & \\
\hline$P$ & TDZ $\triangleleft$ IBA conc & & & & -* & \\
\hline $\mathrm{P}$ & TDZ $\bullet$ IBA overlay duration & & & & $-*$ & \\
\hline $\mathrm{P}$ & Zeatin $\bullet \mathrm{ABA}$ & $-*$ & & & $-* * *$ & \\
\hline $\mathrm{P}$ & Zeatin $\downarrow$ IBA conc & $-*$ & & & & $-* * * *$ \\
\hline $\mathrm{P}$ & Zeatin $\bullet$ IBA overlay duration & & & & & $-* * * *$ \\
\hline $\mathrm{P}$ & $\mathrm{ABA} \downarrow \mathrm{IBA}$ conc & & & & & $-* *$ \\
\hline $\mathrm{P}$ & $\mathrm{ABA} \triangleleft \mathrm{IBA}$ overlay duration & & & & & \\
\hline $\mathrm{P}$ & IBA conc $\triangle$ IBA overlay duration & & & & & $-*$ \\
\hline Y & {$\left[\mathrm{NO}_{3}{ }^{-}\right] \bullet$ Light intensity } & $-* *$ & & & & \\
\hline Y & {$\left[\mathrm{NO}_{3}{ }^{-}\right] \bullet$ Duration of light treatment } & & & & & - ***** \\
\hline $\mathrm{Y}$ & {$\left[\mathrm{NO}_{3}{ }^{-}\right] \bullet \mathrm{BAP}$} & $-* * *$ & & -* & $-*$ & \\
\hline Y & {$\left[\mathrm{NO}_{3}{ }^{-}\right] \bullet \mathrm{TDZ}$} & & & & & \\
\hline Y & {$\left[\mathrm{NO}_{3}^{-}\right]$zeatin } & & & & & \\
\hline $\mathrm{Y}$ & {$\left[\mathrm{NO}_{3}^{-}\right] \triangleleft \mathrm{ABA}$} & & & & -* & \\
\hline $\mathrm{Y}$ & {$\left[\mathrm{NO}_{3}{ }^{-}\right] \bullet \mathrm{IBA}$ conc } & & & & & \\
\hline
\end{tabular}


Table 5 (continued)

\begin{tabular}{|c|c|c|c|c|c|c|}
\hline Code & Source & $\begin{array}{l}\text { Tissue morphology } \\
\text { score }\end{array}$ & $\begin{array}{l}\% \text { shoot to } \\
\text { rooting }\end{array}$ & $\begin{array}{l}\% \text { plant sent } \\
\text { to GH }\end{array}$ & $\begin{array}{l}\text { \#T0 } \\
\text { survived }\end{array}$ & $\% \mathrm{SCE}$ \\
\hline $\mathrm{Y}$ & {$\left[\mathrm{NO}_{3}{ }^{-}\right] \bullet \mathrm{IBA}$ overlay duration } & & & & -* & \\
\hline $\mathrm{Y}$ & Ratio of $\mathrm{NH}_{4}^{+} / \mathrm{K}^{+} \triangleleft$ light intensity & -*** & & & & $-* *$ \\
\hline $\mathrm{Y}$ & Ratio of $\mathrm{NH}_{4}^{+} / \mathrm{K}^{+}$duration of light treatment & & & & & $-* *$ \\
\hline $\mathrm{Y}$ & Ratio of $\mathrm{NH}_{4}^{+} / \mathrm{K}^{+} \bullet \mathrm{BAP}$ & $-* * * *$ & & & & \\
\hline $\mathrm{Y}$ & Ratio of $\mathrm{NH}_{4}^{+} / \mathrm{K}^{+} \triangleleft \mathrm{TDZ}$ & & & & & -*** \\
\hline $\mathrm{Y}$ & Ratio of $\mathrm{NH}_{4}^{+} / \mathrm{K}^{+}$Zeatin & & & & & \\
\hline $\mathrm{Y}$ & Ratio of $\mathrm{NH}_{4}{ }^{+} / \mathrm{K}^{+}$ABA & $-* * * *$ & & & & -*** \\
\hline $\mathrm{Y}$ & Ratio of $\mathrm{NH}_{4}^{+} / \mathrm{K}^{+} \bullet \mathrm{IBA}$ conc & & & & -* & \\
\hline $\mathrm{Y}$ & Ratio of $\mathrm{NH}_{4}^{+} / \mathrm{K}^{+} \bullet$ IBA overlay duration & -*** & & & & -**** \\
\hline $\mathrm{Y}$ & Light intensity $\triangleleft \mathrm{BAP}$ & & & & & \\
\hline $\mathrm{Y}$ & Light intensity $\triangleleft D Z$ & $-* *$ & & & & $-* *$ \\
\hline $\mathrm{Y}$ & Light intensity zeatin & & & & & \\
\hline $\mathrm{Y}$ & Light intensity $\mathrm{ABA}$ & $-*$ & & & $-* *$ & \\
\hline $\mathrm{Y}$ & Light intensity $\triangleleft$ IBA conc & & & & & -** \\
\hline $\mathrm{Y}$ & Light intensity $\triangleleft$ IBA overlay duration & & & & $-* *$ & $-* * * *$ \\
\hline $\mathrm{Y}$ & Duration of light treatment $\mathrm{BAP}$ & $-*$ & $-*$ & & -** & \\
\hline $\mathrm{Y}$ & Duration of light treatment $\mathrm{TDZ}$ & & & & $-*$ & $-* * * *$ \\
\hline Y & Duration of light treatment zeatin & $-*$ & & & & $-* * * *$ \\
\hline $\mathrm{Y}$ & Duration of light treatment $\mathrm{ABA}$ & & & & & \\
\hline $\mathrm{Y}$ & Duration of light treatment IBA conc & $-* *$ & & & & \\
\hline $\mathrm{Y}$ & Duration of light treatment $\downarrow$ IBA overlay duration & & & & -* & $-*$ \\
\hline
\end{tabular}

The whole model fit was calculated for each response by R-squared and R-squared adjusted. Factors were categorized as nutrient (N), light (L), plant growth regulator $(\mathrm{P})$, and other second interactions $(\mathrm{Y})$. Single-copy transgenic event (SCE)

$*$ Prob $<0.05 ; * *$ Prob $<0.01 ; * * *$ Prob $<0.001 ; * * * *$ Prob $<0.0001$ - significance levels by Prob $>t$

$A B A$, abscisic acid; $B A P$, 6-benzylaminopurine; $I B A$, indole-3-acetic acid; $T D Z$, thidiazuron; $\mathrm{NH}_{4}^{+} / \mathrm{K}^{+}$, ratio of $\left[\mathrm{NH}_{4}^{+}\right]$to $\left[\mathrm{K}^{+}\right] ;\left[N O_{3}^{-}\right]$, nitrate concentration
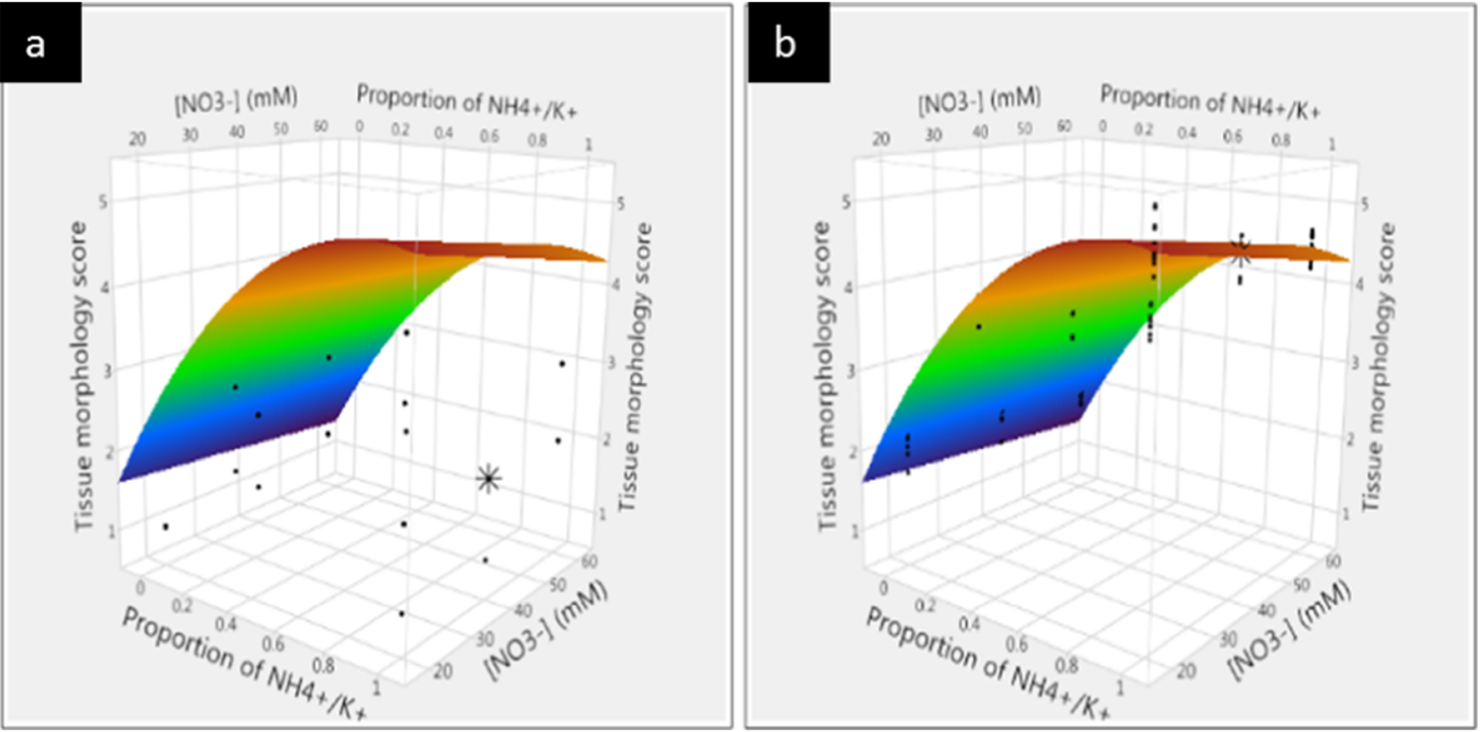

Fig. 5 The effect of the ratio of $\mathrm{NH}_{4}^{+} / \mathrm{K}^{+}$and $\left[\mathrm{NO}_{3}{ }^{-}\right]$on Zea mays L. tissue morphology. (a) Actual data; $(b)$ predicted data with the ratio of $\mathrm{NH} 4^{+} / \mathrm{K}^{+}$ and $\left[\mathrm{NO}_{3}{ }^{-}\right]$at tested values, and all other factors at optimal values. The asterisk is the control treatment value; black dots represent other treatment values 


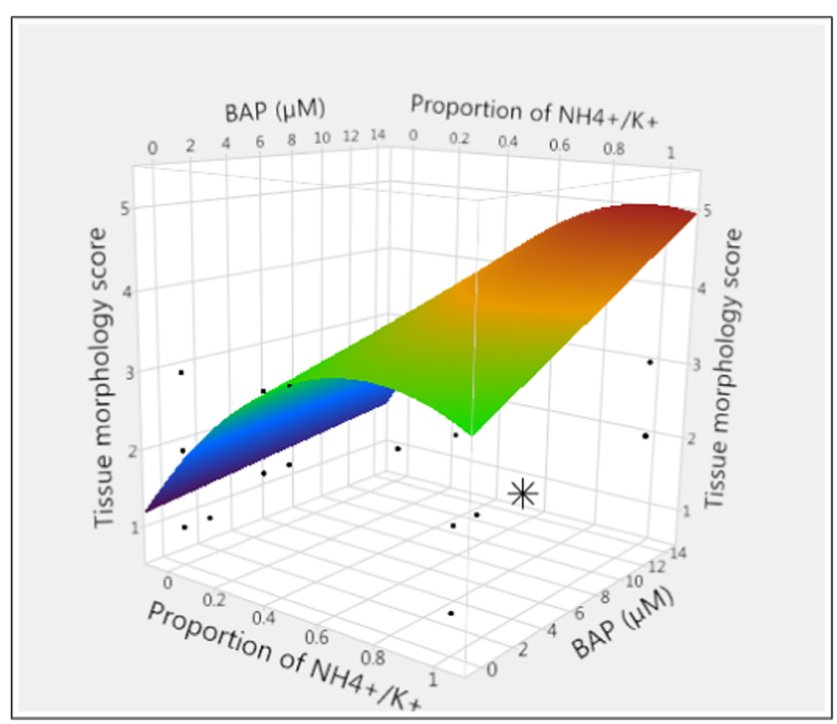

Fig. 6 The effect of ratio of $\mathrm{NH}^{+} / \mathrm{K}^{+}$and 6-benzylaminopurine (BAP) on Zea mays L. tissue morphology. The asterisk is the control treatment value; black dots represent other treatment values

development than for tissue morphology (Table 5). Light duration was the only highly significant factor to promote the formation of green leafy shoots that were suitable for transfer to rooting medium. The interaction between light intensity and duration of light had a quadratic term (Fig. 10). The shoot-torooting percentage was highest when the duration of exposure to light was at $12 \mathrm{~d}$ and the light intensity approximately $140 \mu \mathrm{mol} \mathrm{m} \mathrm{m}^{-2} \mathrm{~s}^{-1}$. The light intensity in this case is higher than what was optimal for tissue morphology $\left(50 \mu \mathrm{mol} \mathrm{m}{ }^{-2} \mathrm{~s}^{-1}\right)$. The control treatment (asterisk, Fig. 10) was $7 \mathrm{~d}$ of light exposure $\left(60 \mu \mathrm{mol} \mathrm{m} \mathrm{m}^{-2} \mathrm{~s}^{-1}\right)$ and had $48 \%$ of the shoots moved to rooting medium. A 12-d exposure to light

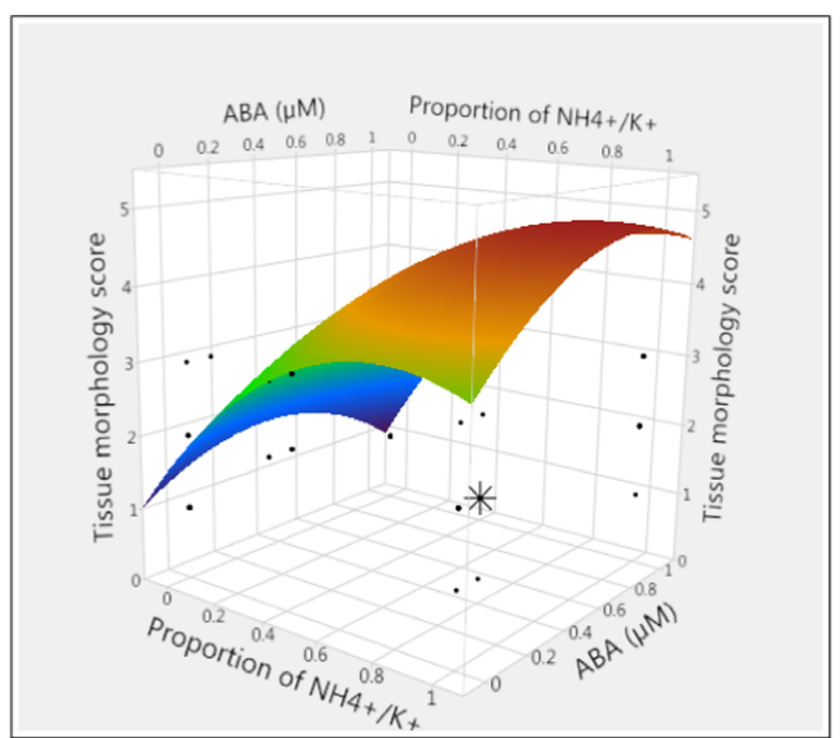

Fig. 7 The effect of ratio of $\mathrm{NH}_{4}{ }^{+} / \mathrm{K}^{+}$and abscisic acid (ABA) on Zea mays L. tissue morphology. The asterisk is the control treatment value; black dots represent other treatment values

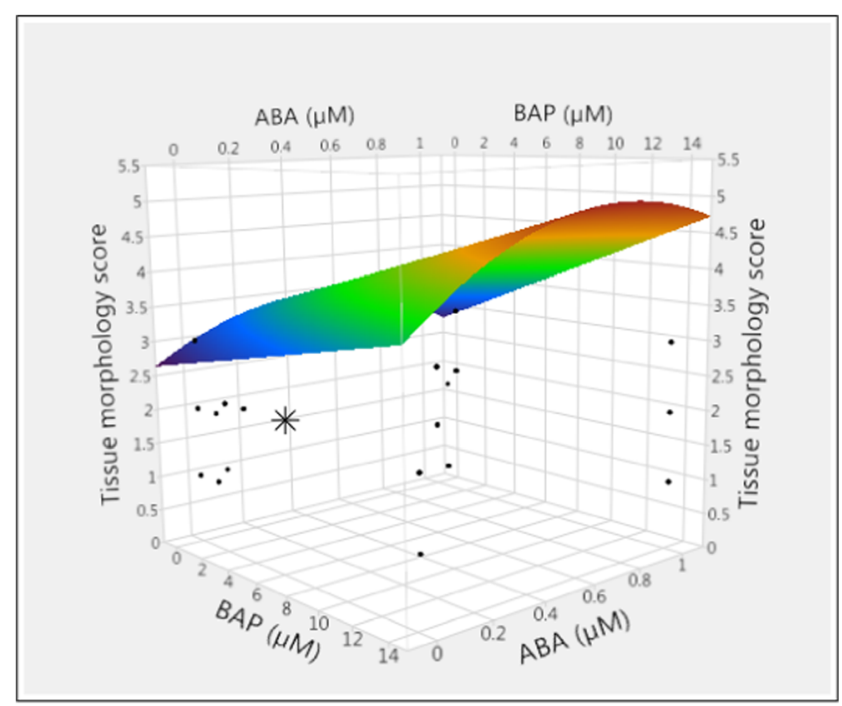

Fig. 8 The effect of 6-benzylaminopurine (BAP) and abscisic acid (ABA) on Zea mays L. tissue morphology. The asterisk is the control treatment value; black dots represent other treatment values

at $140 \mu \mathrm{mol} \mathrm{m} \mathrm{m}^{-2} \mathrm{~s}^{-1}$ yielded the most shoots capable of successful rooting.

Ratio of $\mathrm{NH}_{4}{ }^{+} / \mathrm{K}^{+}$and $\left[\mathrm{NO}_{3}{ }^{-}\right.$] effects on percentage of plants sent to GH The control treatment (asterisk, Fig. 9) had 24\% of plants sent to the $\mathrm{GH}$ and was located far from the optimal profile surface (Fig. 11). The optimal macronutrient combination to produce rooted shoots with healthy leaves was not tested in the DoE, but it was predicted (Table 5). With other factors optimized, the ideal values for the ratio of $\mathrm{NH}_{4}^{+} / \mathrm{K}^{+}$was predicted to be 0.6 and $\left[\mathrm{NO}_{3}\right]$ would be approximately $40 \mathrm{mM}$ and the potential percentage of plants sent to the GH would be $129 \%$.

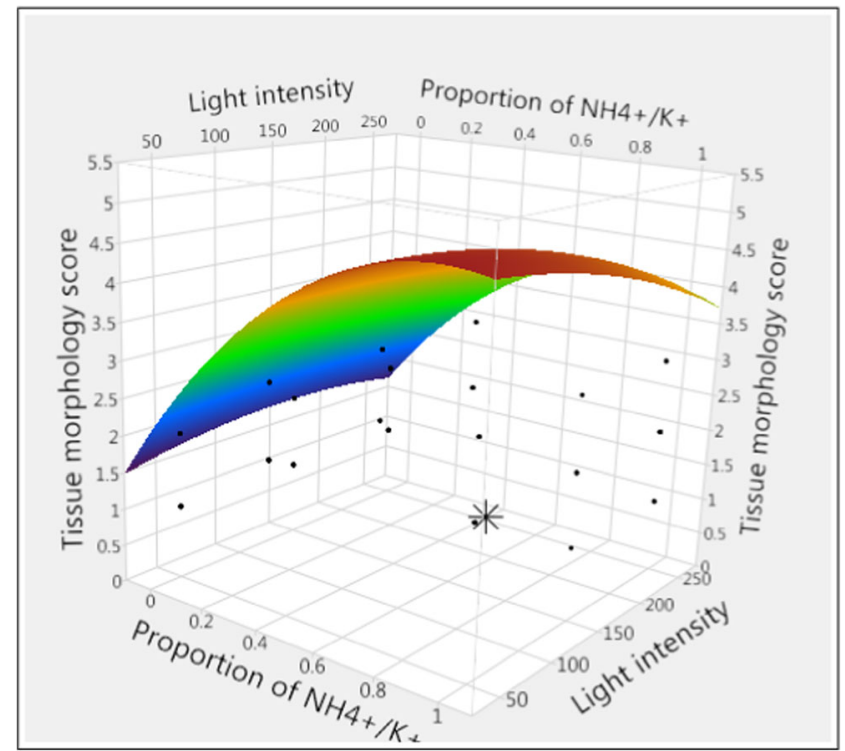

Fig. 9 The effect of ratio of $\mathrm{NH}_{4}^{+} / \mathrm{K}^{+}$and light intensity on Zea mays L. tissue morphology. The asterisk is the control treatment value; black dots represent other treatment values 


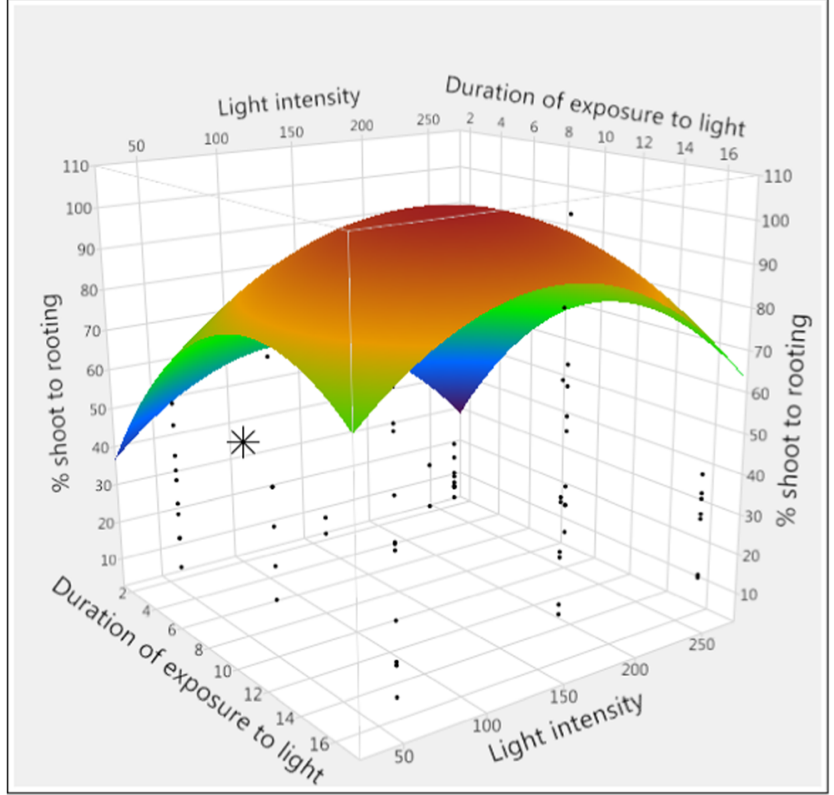

Fig. 10 The effect of duration of exposure to light and light intensity on $\%$ shoots to rooting of Zea mays L. regenerants. The asterisk is the control treatment value; black dots represent other treatment values

TDZ and BAP effects on percentage of plants sent to GH 6Benzylaminopurine and TDZ were independent effects as main factors (Table 5). The percentage of plants sent to the GH was highest at 7.4 $\mu \mathrm{M}$ BAP, regardless of the TDZ concentration (Fig. 12). Eliminating TDZ had a slightly negative effect compared with the optimal $0.1 \mu \mathrm{M}$, while increasing TDZ to higher levels reduced the number of plants sent to the GH. The control treatment, at $4.4 \mu \mathrm{M}$ BAP and

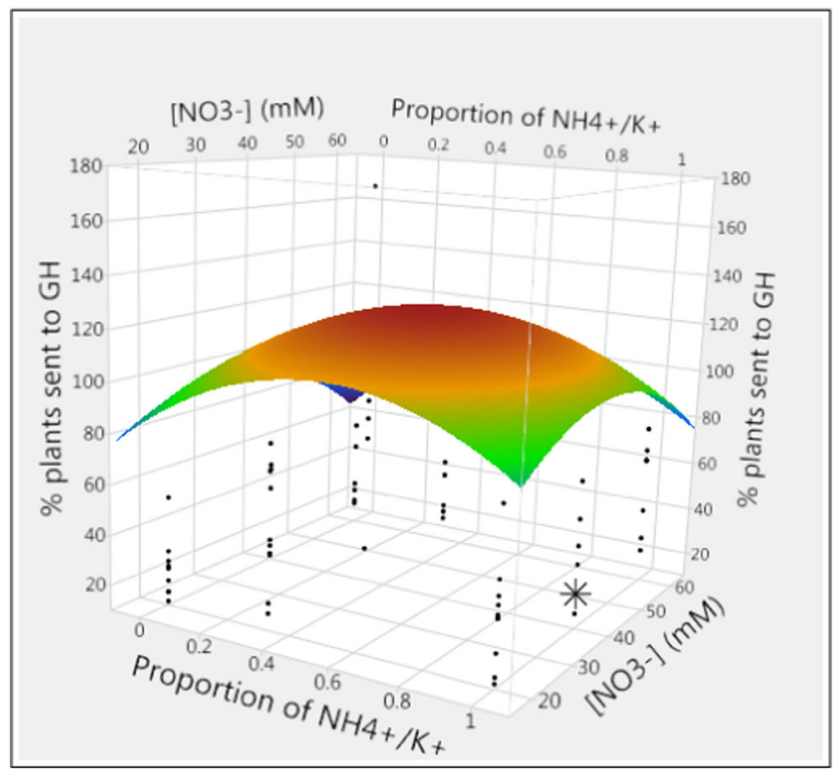

Fig. 11 The effect of ratio of $\mathrm{NH}_{4}{ }^{+} / \mathrm{K}^{+}$and $\left[\mathrm{NO}_{3}{ }^{-}\right]$on $\%$ Zea mays $\mathrm{L}$. plants sent to the greenhouse. The asterisk is the control treatment value; black dots represent other treatment values

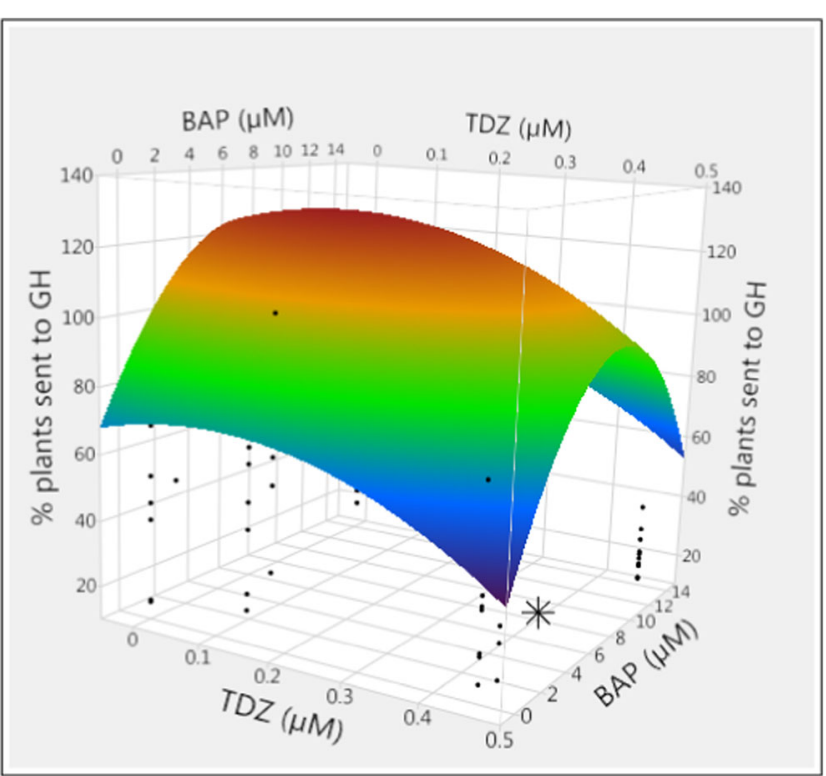

Fig. 12 The effect of thidiazuron (TDZ) and 6-benzylaminopurine (BAP) on the \% Zea mays L. plants sent to the greenhouse. The asterisk is the control treatment value; black dots represent other treatment values

$0.455 \mu \mathrm{M}$ TDZ, had levels of BAP that were too low and levels of TDZ that were too high, with only $24 \%$ of the plants sent to the GH.

The optimal setting to obtain the highest percentage of plants (per starting embryos) sent to the $\mathrm{GH}$ was at a 0.6 ratio of $\mathrm{NH}_{4}{ }^{+} / \mathrm{K}^{+}$at $40 \mathrm{mM}$ total $\left[\mathrm{NO}_{3}{ }^{-}\right], 7.4 \mu \mathrm{MBAP}$, and $0.1 \mu \mathrm{M}$ TDZ and a possibility to achieve a greater than $100 \%$ frequency of plants sent to the GH (greater than 1 plant regenerated per starting embryo).

Ratio of $\mathrm{NH}_{4}{ }^{+} / \mathrm{K}^{+}$and total $\left[\mathrm{NO}_{3}{ }^{-}\right]$effects on T0 survival Similar to tissue morphology, the survival of T0 plants in the $\mathrm{GH}$ was determined by many significant factors. Considering the nutrient factors, seven T0s from the control treatment (asterisk, Fig. 13) survived in the GH, a number lower than predicted by the modeled surface (Fig. 13a). The highest number of T0 (41) predicted to survive in the $\mathrm{GH}$ was at a 0.6 ratio of $\mathrm{NH}_{4}{ }^{+} / \mathrm{K}^{+}$and approximately $30 \mathrm{mM}$ total $\left[\mathrm{NO}_{3}{ }^{-}\right]$. The upward shift of data points from Fig. $13 a$ to the optimal condition in Fig. $13 b$ is explained by many significant factors, other than the nutrient factors plotted in Fig. 13.

TDZ and light intensity and BAP and duration of light exposure effects on T0 survival The survival of T0 plants was increased at higher light intensities, with a maximum intensity at approximately $250 \mu \mathrm{mol} \mathrm{m} \mathrm{m}^{-2} \mathrm{~s}^{-1}$. Thidiazuron was detrimental to GH survival except at low levels (Fig. 14). A small concentration of TDZ $(0.1 \mu \mathrm{M})$, yielded slightly better survival than omission of TDZ. T0 survival was highest at $7.4 \mu \mathrm{M}$ BAP and $11 \mathrm{~d}$ exposure to light (Fig. 15). 


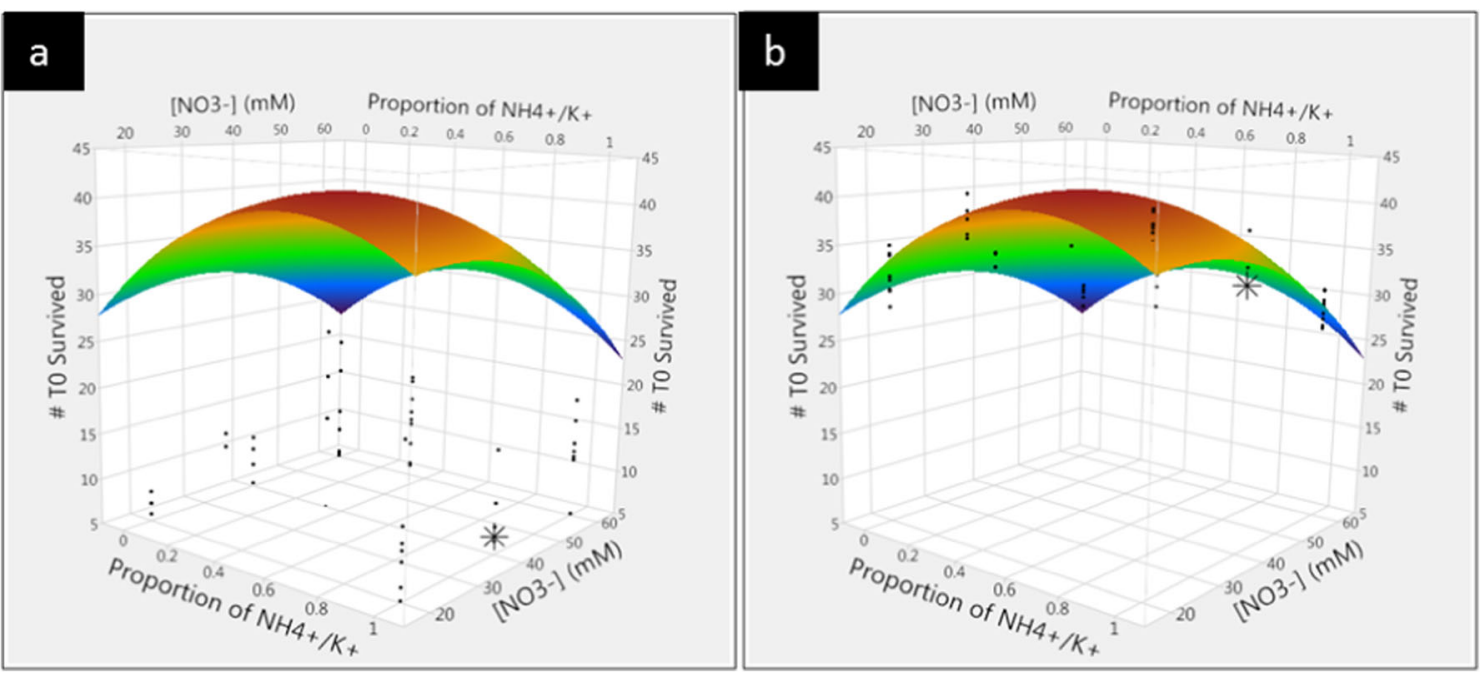

Fig. 13 The effect of ratio of $\mathrm{NH}_{4}{ }^{+} / \mathrm{K}^{+}$and $\left[\mathrm{NO}_{3}{ }^{-}\right]$on Zea mays L. tissue morphology. (a) Actual data and $(b)$ predicted data with the ratio of NH4 $4^{+} / \mathrm{K}^{+}$ and $\left[\mathrm{NO}_{3}{ }^{-}\right]$at tested values and all other factors at optimal values. The asterisk is the control treatment value; black dots represent other treatment values

ABA and light intensity effects on TO survival Without ABA in the medium, a low light intensity was required. When the medium contained the highest amounts of ABA $(1 \mu \mathrm{M})$, a higher light intensity $\left(250 \mu \mathrm{mol} \mathrm{m} \mathrm{m}^{-2} \mathrm{~s}^{-1}\right)$ was needed to get the most T0 plant survival in the GH (Fig. 16).

BAP and zeatin effects on T0 survival Zeatin had no effect on T0 survival or a negative effect when added with BAP. At 14.2 $\mu \mathrm{M}$ BAP, adding zeatin had a negative impact on the number of T0 plants that survived in GH. The optimal BAP concentration was $7.4 \mu \mathrm{M}$ without zeatin.

The overall optimal setting to obtain the highest number of T0 plants that survived in the $\mathrm{GH}$ was a 0.6 ratio of $\mathrm{NH}_{4}{ }^{+} / \mathrm{K}^{+}$,

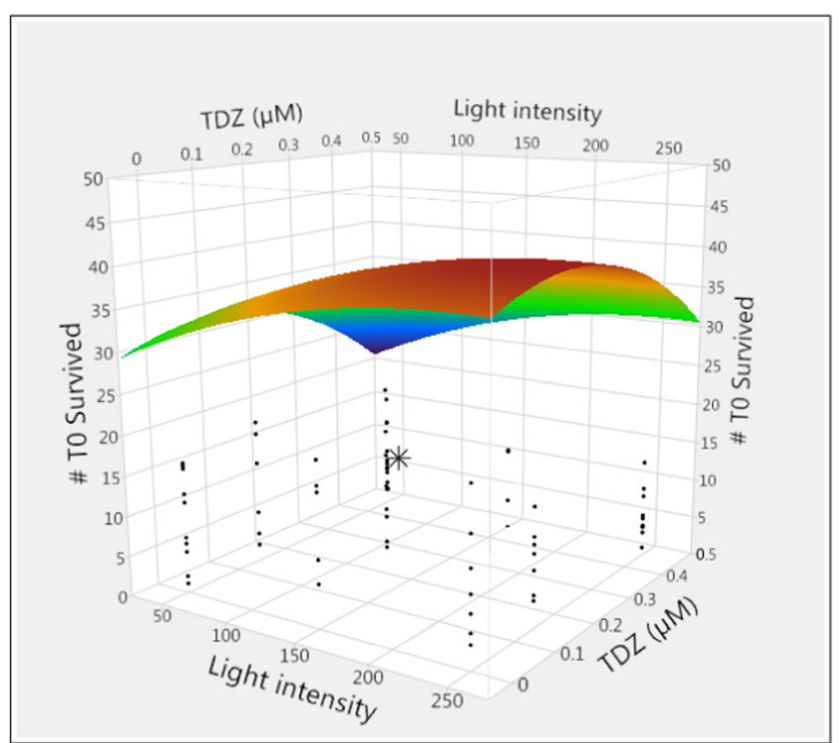

Fig. 14 The effect of thidiazuron (TDZ) and light intensity on the number of Zea mays L. T0 survived. The asterisk is the control treatment value; black dots represent other treatment values
$40 \mathrm{mM}\left[\mathrm{NO}_{3}{ }^{-}\right], 0.1 \mu \mathrm{M}$ TDZ, $7.4 \mu \mathrm{M}$ BAP, no zeatin, $1 \mu \mathrm{M}$ ABA, $11 \mathrm{~d}$ exposure to light, and $250 \mu \mathrm{mol} \mathrm{m}{ }^{-2} \mathrm{~s}^{-1}$ of light intensity.

Validation result All three treatments were superior to the control treatment for $\%$ plants sent to the GH. The model predicted the $\%$ plants sent to the $\mathrm{GH}$ to be within the ranges of 62 to 175,14 to 155,49 to $178 \%$ for treatments A, B, and C, respectively, and the observed values of 67,94 , and $100 \%$, respectively, were within the expected ranges predicted by the model. The new processes met the objective, with greater percentages of plants sent to the $\mathrm{GH}$ than the control treatment $(47 \%)$. A requirement was

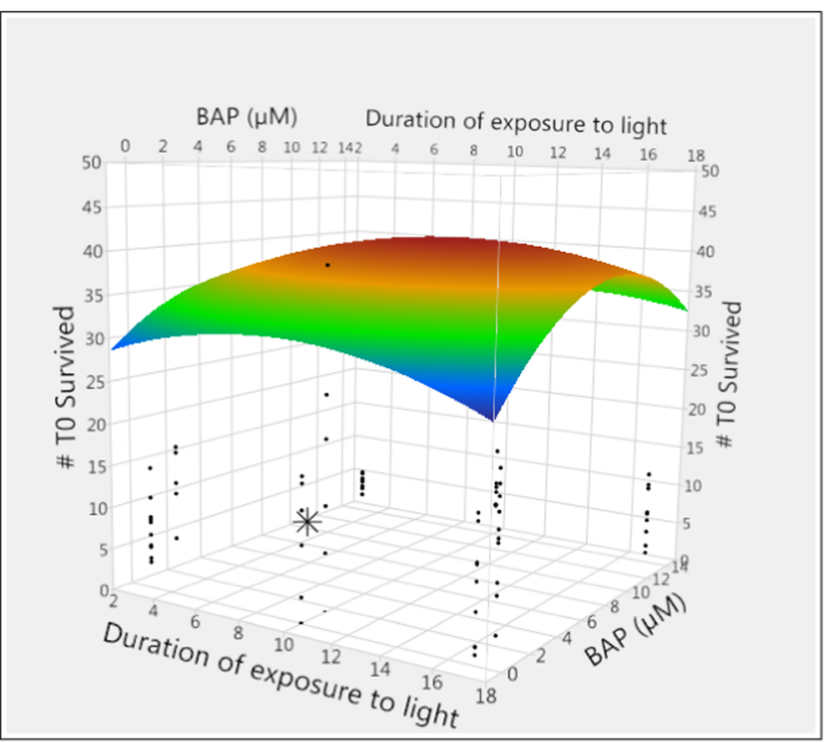

Fig. 15 The effect of duration of exposure to light and 6benzylaminopurine (BAP) on the number of Zea mays L. T0 survived. The asterisk is the control treatment value; black dots represent other treatment values 


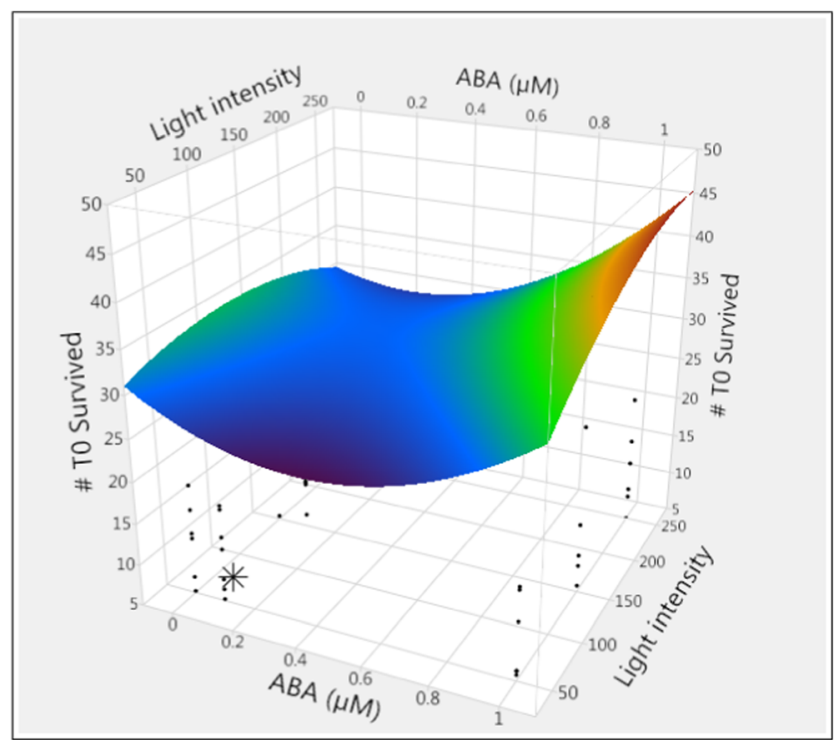

Fig. 16 The effect of abscisic acid (ABA) and light intensity on the number of Zea mays L. T0 survived. The asterisk is the control treatment value; black dots represent other treatment values

satisfied to maintain $\mathrm{SCE} \%$ similar to the control for the process to be useful for production purposes (Table 6). Final event percentage (FE\%) represents the frequency of single-copy events based on starting zygotic embryos and is a meaningful measurement of efficiency for a production process. Final event percentage $(\mathrm{FE} \%)$ was maintained or improved in the new processes (Table 6). The model was not precise in delimiting the ranges of plants sent to the GH. The model did not predict SCE\% well either, but that was not a specific objective of this study.

\section{Discussion}

The DoE approach was useful to design and identify parameters to address plant quality problems during the regeneration and maturation of somatic embryos using the new transformation process. The macronutrient ions, ammonium, nitrate, and potassium were critically important in the continuum of responses. Using this platform, correct nutrient combinations were identified, along with their interactions with the other environmental parameters of light and plant growth regulators. The limitation to this DoE may in part come from the optimality criteria, d-optimal, used to subset the selection of treatments. Most of the selected points in d-optimal designs were in the corners of the modeled space, with values being at the highest and lowest ends of the parameter's range. This weighting allowed for accurate identification of the important parameters, and their interactions, and indicated if the factors were tested within the optimal range required for each response. The d-optimal selections contained very few points in the interior of the model's space and were not accurate for defining the coordinate points for the maximal response. This was apparent in the validation, in which the useful factor level combinations were chosen, but predictions of the optimal outcomes were not precise.

Nitrogen quantity and the molecular form has been the subject of many media optimization studies with maize. In contrast with the conventional system, the accelerated development of the somatic embryos required optimal nutrient availability, especially because the somatic embryos must mature quickly, directly, and sufficiently to activate the excision/ selection system. The new, rapid transformation system uses the two morphogenic genes WUS2 and BBM to stimulate somatic embryogenesis from immature zygotic embryos and direct germination of somatic embryos without a callus phase (Lowe et al. 2018). The procedure was modified for excision/ selection using GLB1:moCRE and a split, inactivated HRA cassette. During normal embryo development, the GLB1 promoter becomes active resulting in excision of the morphogenic genes and reconstitution of the HRA cassette. This ensures that only excised events survive selection.

During early embryo development in the new process, the ratio of $\mathrm{NH}_{4}{ }^{+} / \mathrm{K}^{+}$was a highly significant factor. The optimal tissue morphology response was at a ratio of one for $\mathrm{NH}_{4}{ }^{+} / \mathrm{K}^{+}$
Table 6 Validation experiment results

\begin{tabular}{|c|c|c|c|c|c|c|}
\hline \multirow[t]{2}{*}{ Treatment } & \multicolumn{3}{|l|}{ Predicted ranges } & \multicolumn{3}{|l|}{ Actual } \\
\hline & $\%$ plants sent to $\mathrm{GH}$ & SCE\% & FE\% & $\%$ plants sent to $\mathrm{GH}$ & SCE\% & FE\% \\
\hline A & $62-175$ & $13-25$ & $5-12$ & 67 & 26 & 14 \\
\hline B & $14-155$ & $22-37$ & $7-17$ & 94 & 15 & 11 \\
\hline $\mathrm{C}$ & 49-178 & $19-32$ & $7-15$ & 100 & 13 & 11 \\
\hline Control & & & & 47 & 16 & 6 \\
\hline
\end{tabular}

The experiment included four treatments: (A) a treatment designed to get a high percentage of Zea mays L. plants sent to the greenhouse (GH); (B) a treatment designed to get a high percentage of single-copy transgenic event (SCE); (C) a harmonized treatment designed for both, and a control treatment at the current condition. While the model for optimal light intensity for treatment $A$ utilized light emiting diodes (LED) lighting at $135 \mu \mathrm{mol} \mathrm{m}^{-2} \mathrm{~s}^{-1}$, the experiment was conducted under fluorescent light at $60 \mu \mathrm{mol} \mathrm{m} \mathrm{s}^{-1}$. Final event (FE) 
and $20 \mathrm{mM}\left[\mathrm{NO}_{3}{ }^{-}\right.$]. This ratio produced tissue with the most desirable phenotype, with small, single, and well-formed shoots that were strong and turgid. Murashige and Skoog (1962) MS medium, containing equal amounts of $\mathrm{NH}_{4}{ }^{+}$to $\mathrm{K}^{+}$at $40 \mathrm{mM}\left[\mathrm{NO}_{3}{ }^{-}\right]$has historically been used for maize regeneration and rooting. Later in development, to maximize the percentage of plants sent to the $\mathrm{GH}$, and number of plants that survived in the $\mathrm{GH}$, the concentration of nitrate should be $40 \mathrm{mM}$. But unlike MS medium, the optimal ratio of $\mathrm{NH}_{4}{ }^{+} / \mathrm{K}^{+}$ was predicted to be 0.6 . Therefore, increasing the amount of $\mathrm{KNO}_{3}$ and decreasing $\mathrm{NH}_{4} \mathrm{NO}_{3}$ compared with MS basal medium should improve the percentage of plants sent to the $\mathrm{GH}$ and the number of $\mathrm{T} 0$ plants surviving. This macronutrient blend was never tested in the DoE but was a significant component of the validation. The validation confirmed that later stages of somatic embryo maturation required less $\mathrm{NH}_{4} \mathrm{NO}_{3}$ than $\mathrm{KNO}_{3}$. Preference for reduced or oxidized forms of inorganic nitrogen changed during the conversion of shoot buds to leafy shoots. The production of quality leafy shoots produced in vitro correlated well with the survival of healthy, robust plants in the GH, which validated the scoring system.

Nitrogen is known to effect endogenous cytokinin levels and responses to exogenous auxin (Grimes and Hodges 1990; Argueso et al. 2009). 6-Benzylaminopurine was preferred as a cytokinin source, with TDZ and zeatin antagonizing the desired responses. Initially, the highest BAP levels of $14.2 \mu \mathrm{M}$ were preferred, and the best tissue morphology required more $\mathrm{ABA}$ (up to $0.7 \mu \mathrm{M}$ ). Subsequently, rooted plants suitable to send to the GH required a reduced BAP concentration of $7.4 \mu \mathrm{M}$ and an ABA concentration up to $1 \mu \mathrm{M}$. Unlike a conventional callusbased approach, this system is biased toward embryogenesis by requiring expression of GLB1, with obligate ABA induction (Rivin and Grudt 1991). The dynamic relationship between the two PGRs was temporal, has seldom been studied, and was correctly identified by the DoE as important. Additional time-course experiments were indicated to further study the relationship.

Embryo development proceeded well with low light levels. Later stages of embryo development required a higher light intensity and more ABA. It is well known in embryo rescue that light promotes precocious germination during embryo rescue (Sharma et al. 1996). At higher light intensity, developing somatic embryos may germinate precociously, prior to globulin gene expression. Therefore, GLB1/moCRE would not be activated and the somatic embryos would be herbicide sensitive. Later, growth at high light intensity and high ABA levels satisfied these conditions. The DoE identified this sequencing as important.

This DoE experiment focused on the "maturation" stage of the transformation process, which is a stage that occurs 1 to 2 wk after $A$. tumefaciens infection. By that time, T-DNA would have already integrated into the genome and the integration pattern would have been established. Although TDNA processing occurs in A. tumefaciens, it was observed that integration complexity varies depending on the medium and genotype. A high frequency of multiple-copy transformants has been observed in inbred HC69, when using morphogenic genes compared with conventional transformation (data not shown). Presumably, only a fraction of introduced T-strands integrate, which is a process that is dependent on the growth rate of the host cell. Increased growth rates could therefore increase the chances of integrating incorrectly processed T-strands. Nevertheless, because SCE\% is an important consideration for commercial biotechnology crop development, monitoring SCE\% was important in this study. Interestingly, the type and concentration of cytokinins appeared to influence the SCE\% of regenerated plants. The phenomenon of genotype and tissue culture conditions affecting copy number is widespread but not well understood.

In the new transformation method, the rapid proliferation of somatic embryos appears to be genotype independent, but the conversion of these embryos into plantlets is influenced by both media and genotype. The results presented here were from a single inbred, HC69, and may not be applicable to other genotypes. While this system is rapid and simple, the plantlets regenerated from this inbred often have poor root development and are not synchronized in development due to a prolonged rootformation stage. The "one factor at a time" (OFAT) approaches would have required nutrient levels be fixed, independent of their ratios relative to other nutrients, and in the absence of adequate information on growth regulators. Likewise, growth regulators would need to be fixed in the absence of information on nutrients or light. The chance of optimizing a novel system with so many factors using the OFAT method would be remote. The multifactor approach allows researchers to address complex variables and interactions with their biological systems, in a compressed time frame.

Acknowledgments This work was funded by Corteva Agriscience ${ }^{\mathrm{TM}}$. The authors want to thank Carl Simmons for the design of the synthetic intron with the LoxP site and Craig Hastings for building the vector, Tim Wahl and his media prep team, and Jeffry Farrell and his greenhouse team for plant care. We also want to thank Dr. William Bridges, for statistical analysis, and various reviewers for their helpful comments and critical review of the manuscript.

Open Access This article is distributed under the terms of the Creative Commons Attribution 4.0 International License (http:// creativecommons.org/licenses/by/4.0/), which permits unrestricted use, distribution, and reproduction in any medium, provided you give appropriate credit to the original author(s) and the source, provide a link to the Creative Commons license, and indicate if changes were made.

\section{References}

Anand A, Arling M, Da Silva A, Gordon-Kamm WJ, Hastings CE, Hoester GM, Klein TM, La Rota CM, Lowe KS, Tiwari SB, Wang N, Wu XE (2017) Methods and composition for rapid plant transformation. Patent Number US 2170121722 A1 
Anand A, Bass SH, Wu E, Wang N, McBride KE, Annaluru N, Miller M, Mo H, Jones TJ (2018) An improved ternary vector system for Agrobacterium-mediated rapid maize transformation. Plant Mol Biol 97:187-200

Argueso CT, Ferreira FJ, Kieber JJ (2009) Environmental perception avenues: the interaction of cytokinin and environmental response pathways. Plant Cell Environ 32:1147-1160

Belanger FC, Kriz AL (1991) Molecular basis for allelic polymorphism of the maize Globulin-1 gene. Genetics 129:863-872

Chilton M, Currier T, Farrand SK, Bendich A, Gordon M, Nester E (1974) Agrobacterium tumefaciens DNA and PS8 bacteriophage DNA not detected in crown gall tumors. Proc Natl Acad Sci U S A 71:3672-3676

Condra LW (2001) Reliability improvement with design of experiments. Marcel Dekker AG, New York

Eckes P, Rosahl S, Schell J, Willmitzer L (1986) Isolation and characterization of a light-inducible, organ-specific gene from potato and analysis of its expression after tagging and transfer into tobacco and potato shoots. Mol Gen Genet 205:14-22

Eriksson T (1965) Studies on the growth requirements and growth measurements of cell cultures of Happlopapus gracilis. Physiol Plant 18:976-993

Frame BR, Shou H, Chikwamba RK, Zhang Z, Xiang C, Fonger TM, Pegg SEK, Li B, Nettleton DS, Pei D, Wang K (2002) Agrobacterium tumefaciens-mediated transformation of maize embryos using a standard binary vector vector system. Plant Physiol 129:13-22

Garnaat CW, Lowe KS, Roth BA (2005) Austin responsive promoter sequences and methods of using the same. United States Patent Number US6838593 B2

George EF, Hall MA, De Klerk G (2008) The components of plant tissue culture media II: organic additions, osmotic and $\mathrm{pH}$ effects, and support systems. In: George EF, Hall MA, De Klerk G-J, (eds) Plant propagation by tissue culture. Springer, Dordrecht pp 65-113

Gordon-Kamm WJ, Spenser TM, Mangano ML, Adams TR, Daines RJ, Start WG, O’Brien JV, Chambers SA, Adams WR Jr, Willetts NG, Rice TB, Mackey CJ, Krueger RW, Kausch AP, Lemaux PG (1990) Transformation of maize cells and regeneration of fertile transgenic plants. Plant Cell 2:603-618

Green CE (1982) Somatic embryogenesis and plant regeneration from the friable callus of Zea mays. Plant Tissue Culture 107. In: Akio Fujiwara A (ed) Proceedings, 5th International Congress of Plant Tissue and Cell Culture held at Tokyo and Lake Yamanake, Japan, July 11-16, 1982

Green CE, Phillips RL (1975) Plant regeneration from tissue cultures of maize. Crop Sci 15:417-421

Green JM, Hale T, Pagano MA, Andreassi JL II, Gutteridge SA (2009) Response of 98140 corn with Gat4621 and HRA transgenes to glyphosate and ALS-inhibiting herbicides. Weed Sci 57:142-148

Grimes HD, Hodges TK (1990) The inorganic $\mathrm{NO}_{3}^{-}: \mathrm{NH}_{4}{ }^{+}$ratio influences plant regeneration and auxin sensitivity in primary callus derived from immature embryos of indica rice (Oryza sativa L.). J Plant Physiol 136:362-367

Iglesias VA, Moscone EA, Papp I, Neuhuber F, Michalowski S, Phelan T, Spiker S, Matzke M, Matzkea A (1997) Molecular and cytogenetic analyses of stably and unstably expressed transgene loci in tobacco. Plant Cell 9:1251-1264

Ingham DJ, Beer S, Money S, Hansen G (2001) Quantitative real-time PCR assay for determining transgene copy number in transformed plants. Biotechniques 31:132-141

Kintzios SE, Hiureas G, Shortsianitis E, Sereti E, Blouhos P, Manos C, Makri O, Taravira N, Drossopoulos JB, Holevas CD (1998) The effect of light on the induction, development and maturation of somatic embryos from various horticultural and ornamental species. Acta Hortic (461):427-432

Koprek T, Rangel S, McElroy D, Louwerse JD, Williams-Carrier RE, Lemaux PG (2001) Transposon-mediated single-copy gene delivery leads to increased transgene expression stability in barley. Plant Physiol 125:1354-1362

Lowe K, Wu E, Wang N, Hoerster G, Hasting C, Cho M, Scelonge C, Lenderts B, Chamberlin M, Cushatt J, Wang L, Ryan L, Khan T, Chow-Yiu J, Hua W, Yu M, Banh J, Bao Z, Brink K, Igo E, Rudrappa B, Shamseer PM, Bruce W, Newman L, Shen B, Zheng P, Bidney D, Falco C, Register J, Zhao Z, Xu D, Jones T, GordonKamm W (2016) Morphogenic regulators Baby boom and Wuschel improve monocot transformation. Plant Cell 28:1998-2015

Lowe K, Rota ML, Hoerster G, Hastings C, Wang N, Chamberlin M, Wu E, Jones T, Gordon-Kamm W (2018) Rapid genotype independent maize transformation via direct somatic embryogenesis. In Vitro Cell Dev Biol Plant 54:240-252

Murashige T, Skoog F (1962) A revised medium for rapid growth and bio assays with tobacco tissue cultures. Physiol Plant 15:473-497

Nagaya S, Kato K, Ninomiya Y, Horie R, Sekine M, Yoshida K, Shinmyo A (2005) Expression of randomly intergrated single complete copy transgenes does not vary in Arabidopsis thaliana. Plant Cell Physiol 46:438-444

Niedz RP, Evens TJ (2008) The effects of nitrogen and potassium nutrition on the growth of nonembryogenic and embryogenic tissue of sweet orange (Citrus sinensis (L.) Osbeck). BMC Plant Biol 8(1): 126

Niedz RP, Evens TJ (2016) Design of experiments (DoE) — history, concepts, and relevance to in vitro culture. In Vitro Cell Dev Biol Plant 52:547-562

Qaim M, Kouser S (2013) Genetically modified crops and food security. PLoS One 8(6):e64879. https://doi.org/10.1371/journal.pone. 006487

Ramage CM, Williams RR (2002) Mineral nutrition and plant morphogenesis. In Vitro Cel Dev Biol Plant 398:116-124

Ranch JP, Liebergesell M, Garnaat CW, Huffman GA (2012) Auxotrophic Agrobacterium for plant transformation and methods thereof. Patent Number US8334429B2

Rivin CJ, Grudt T (1991) Abscisic acid and the developmental regulation of embryo storage proteins in maize. Plant Physiol 95:358-365

Schenk RU, Hildebrandt AC (1972) Medium and techniques for induction and growth of monocotyledonous and dicotyledonous plant cell cultures. Can J Bot 50:199-204

Sharma DR, Kaur R, Kumar K (1996) Embryo rescue in plants - a review. Euphytica 89:325-337

Springer W, Green C, Kohn K (1979) A histological examination of tissue culture initiation from immature embryos of maize. Protoplasma 101:269-281

Tilman D, Balzer C, Hill J, Befort BL (2011) Global food demand and the sustainable intensification of agriculture. Proc Natl Acad Sci U S A 108:20260-20264

Vain P, James VA, Worland B, Snape JW (2002) Transgene behaviour across two generations in a large random population of transgenic rice plants produced by particle bombardment. Theor Appl Genet 105:878-889

White CN, Proebsting WM, Hedden P, Rivin CJ (2000) Gibberellins and seed development in maize. I. Evidence that gibberellin/abscisic acid balance governs germination versus maturation pathways. Plant Physiol 122:1081-1088

Zastrow-Hayes GM, Lin H, Sigmund AL, Hoffman JL, Alarcon CM, Hayes KR, Richmond T, May G, Jeddeloh J, Beatty M (2015) Southern-bysequencing: a robust screening approach for molecular characterization of genetically modified crops. Plant Genome 8:1-15 